\title{
PROBLEMS IN MICROBIAL GENETICS
}

JOSHUA LEDERBERG

Deportment of Genetics, University of Wisconsin, Madison, Wis., U.S.

\section{CONTENTS}

Received 5.xii.47

Introduction.

Mendelian inheritance in micro-organisms-

(i) Fungi

(ii) Algae

Modes of genetic variation-

(i) The particulate basis

(ii) Chromosome alteration

(iii) Cytoplasmic transmission

(iv) Heterokaryosis

(v) Polyploidy

(vi) Autogamic phenomena

(vii) Heterogamic phenomena

(viii) Gene mutation

(ix) Enzymatic adaptation and antibody production

Mutagenesis, or the induction of mutations Mutagens
Materials for mutation study: mutant characters-

(i) Nutritional mutants

(ii) Fermentative mutants

(iii) Phage resistance

(iv) Drug resistance

(v) Antigenic variation

Gene recombination in bacteria and bacteriophage-

(i) Materials for recombination study

(ii) Recombination in bacteriophage

Transformations

Evolution and microbial populations-

(i) Physiological evolution

(ii) Population studies

(iii) On the origin of "new" genes

Conclusion

\section{INTRODUCTION}

Trrs review is addressed to the geneticist who is interested not only in the recent accomplishments of microbial genetics, but also in the prevailing philosophy of, and the methods used by, the workers who are engaged in solving its problems. In compiling this information, the writer has drawn upon many sources, both published and private, to which it will not always be possible to make specific reference. Considerable related information may be found in reviews by Luria (1947b), Beadle (1945b), Lindegren (1945) and Sonneborn (1947a) who deal, respectively, with bacteria, Neurospora, yeasts, and protozoa. The cytology of microbes is beyond the scope of the writer's special capacities, and the reader is referred to discussions by Robinow (1944), Boivin (1947), Lindegren (1945) and Nagel (1946).

By microbes, we shall understand all organisms which can be and are habitually propagated vegetatively from single cells. Our definition includes, then, the thallophytes, the algx, protista, and by extension of the term "cell" the filtrable viruses. The problems of protozoal genetics have been so well discussed by the most competent authority (Sonneborn, 1947a) that only passing references will be made to that group. 
The main directions of difference between genetic study of microand of macro-organisms are in the greater emphasis which has been placed upon the analysis of variation in the one, and of hereditary transmission in the other. The microbial characteristics which are obviously responsible for this differentiation include: (a) clonal reproduction, which leaves new variation as the sole source of hereditary difference; $(b)$ the haploid state which permits the immediate manifestation of recessive mutations which might otherwise be masked ; $(c)$ difficulties, in some forms, in provoking and manipulating the sexual stages ; and $(d)$ difficulties in cytological technique owing, in part, to the small size of the chromosomes. Although some of these properties impede classical breeding studies, they compensate by providing study material in gene change and action.

\section{MENDELIAN INHERITANCE IN MICRO-ORGANISMS}

Recent investigations have shown that genetic characters in many moulds, yeast, and protozoa are transmitted to sexual offspring in typical Mendelian fashion (appropriately modified by haploid inheritance). No exception has, therefore, been taken to the conclusion that most of the hereditary material of these organisms is carried in typical chromosomal systems.

\section{(i) Fungi}

Examples of recent researches involving hybridisation of fungi, particularly Ascomycetes, are collected in table I. The properties of various species which determine their usefulness for genetic work are also summarised there.

A fortunate peculiarity of many Ascomycetes is the preservation of all the products of a single meiosis in a single ascus. In the most favourable forms, the ascospores are arranged in a linear order corresponding to the segregation of the four chromatids of each bivalent. The ascus arrangements AAaa and AaAa, called first- and second-division segregation respectively, depend in the first case on recombination between the centromere and neither or both the $\mathrm{A}$ factors in the tetrad, while " second-division segregation" is the result of recombination between the centromere and one only of the " $A$ "s (Dodge, I940 ; Lindegren, I942 ; Ryan, 1943). Usually, each reduced nucleus undergoes an additional mitosis before the spores are cut out, so that each meiotic product is represented in one of the four pairs of ascospores in the typical 8-spored ascus. Segregation in the promycelium of Basidiomycetes is believed to follow the same pattern, but there is no direct proof of the crossover basis of first- and second-division segregation.

The Mendelian system of recombining particles is the one indicated by most researches on filamentous fungi. Yeasts, at least in some pedigrees, have given equally orthodox results. Tetrad analysis in 
fungi has, however, uncovered certain instances of exceptional chromosome behaviour that are not revealed by less penetrating methods.

In Neurospora, Lindegren and Lindegren (I942) have demonstrated specific patterns of chromatid interference. Unfortunately, the markers were morphological mutants which some workers have found difficult to classify, at least in combinations. This fungus is unquestionably very well suited to the analysis of crossing-over, and fortunately there are now available an unlimited number of biochemical mutant markers which can be scored without ambiguity in any combination. It is to be hoped that the current revival of interest in crossing-over may motivate a reinvestigation of interference in Neurospora.

The coprophilous species Bombardia lunata exhibits some autonomous characters of the ascospores. Segregation of these characters can be determined by inspection, thus circumventing the necessity of manual isolation and transfer of each spore. From data tabulated by Zickler (1934), Catcheside (I944) inferred that the segregation was polarised, the mutant allelomorph tending to the proximal pole of the ascus. Elucidation of the mechanism operating has been hindered by our ignorance of Zickler's whereabouts and of his unique Bombardia cultures. Attempts to recover comparable species from field collections have been unsuccessful, Dr Catcheside tells me.

A different sort of bias, affecting the proportions of symmetrical (AaaA or aAAa) and asymmetrical modes of post-reduction, has been studied by Whitehouse and Haldane (1946). They suggested that asymmetrical segregation will result from the retention of crossover chromatids medially, the non-crossover chromatids more usually reaching the poles, and the preservation through the second division of this orientation. Their analysis of data from diverse sources suggested a doubtfully significant excess of asymmetric reductions.

Shay and Keitt (1945) tested segregating asci of the apple scab fungus Venturia inequalis, from a somewhat different viewpoint. Cytological study had been inconclusive as to the possible rearrangement of nuclei in the developing ascus as might prevent discrimination between first- and second-division segregations. Breaking the order in the four-nucleus stage would result in spurious, asymmetric postreductions in asci in which there had actually been a first-division segregation. Other things being equal, this would result in an excess of asymmetric asci, which was not found, however, for factors controlling pathogenicity on differential hosts.

The mathematical problems of tetrad analysis have been discussed by Mather (1935) and Mather and Beale (1942). Complete analysis depends on the recovery of spores in intact linear order; but some information can be obtained as to centromere relations of factors even in tetrads, such as yeast asci, where the linear order is not preserved. If two independent factors are both closely linked to a centromere, the majority of asci will contain either two parental combinations or 


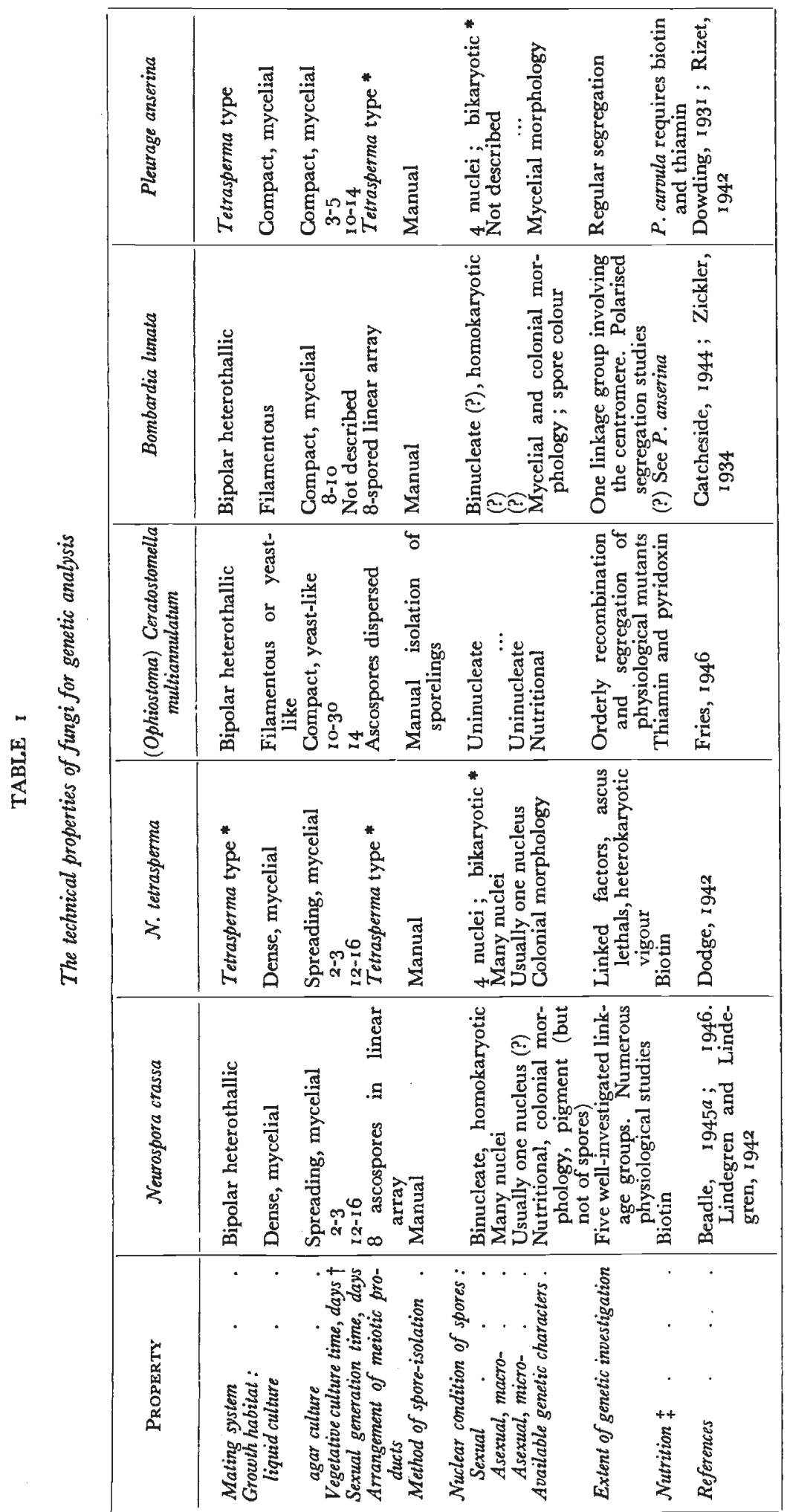




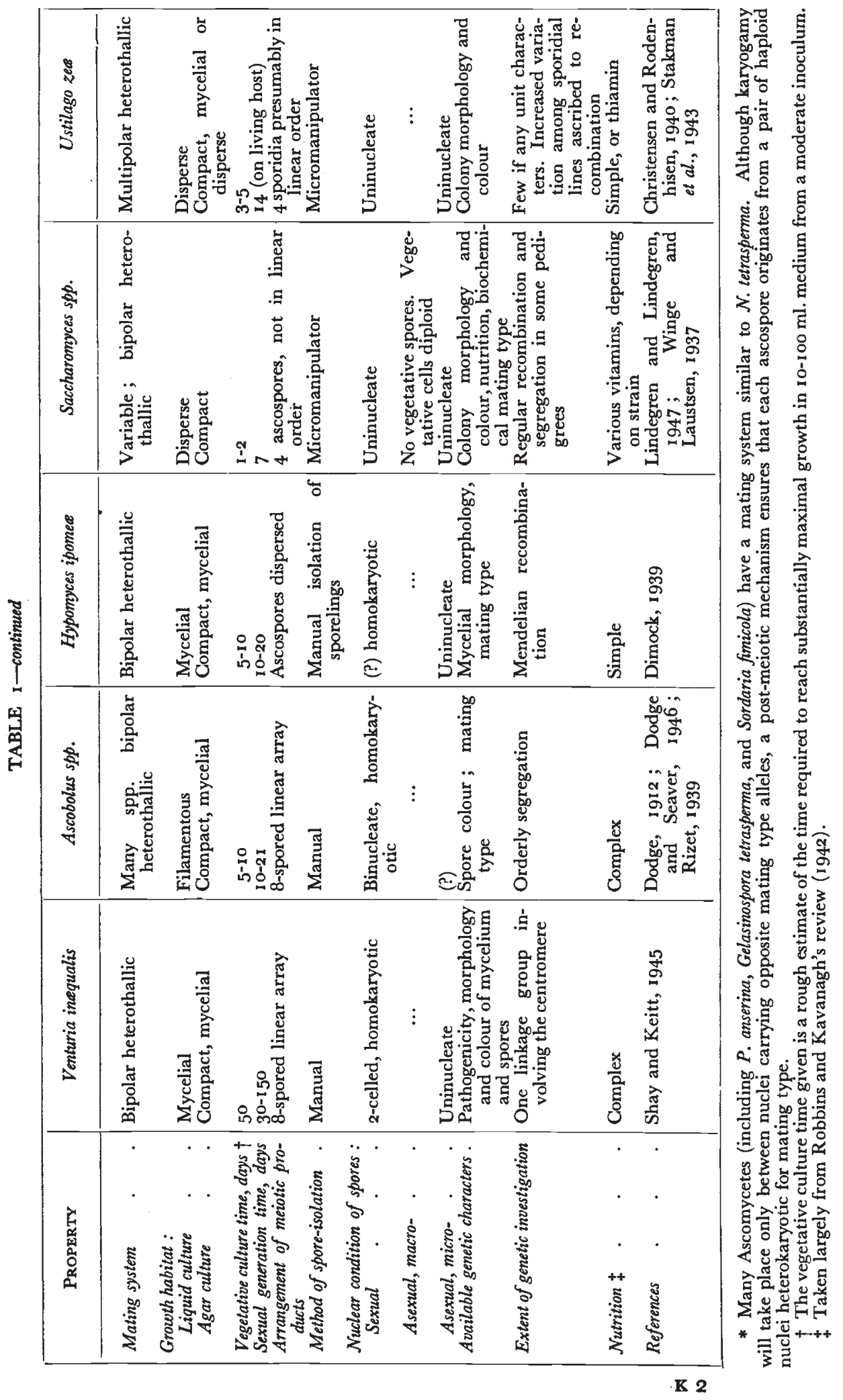


two non-parental combinations, i.e. will be ditype. A loose linkage of one factor to a centromere, on the contrary, is reflected in an increased proportion of tetratype tetrads, containing two parental and two recombinant spores.

Difficulties in the isolation of sexual spores hinder the analysis of smuts and rusts; they have been studied nevertheless on account of their economic importance. The genetics of the rusts have been advanced to a remarkable extent, considering that they are obligate parasites. Many factors controlling virulence on a series of host testers have been shown to mendelise, as have certain factors controlling pigmentation (Johnson, 1946). An outstanding exception will be referred to in relation to cytoplasmic inheritance.

The related group of the smuts has not yielded such clear-cut results on genetic analysis. Although recent reviews (Christensen and Rodenhiser, I940 ; Christensen et al., 1947) refer to a few cases of apparently straightforward Mendelian behaviour, there are many exceptions which have not been adequately explained. For example, Christensen (I93I) and Bauch (I932) have described "solopathogenic" or "hermaphroditic" sporidia. The most likely a priori interpretation of these failures of reduction of mating factors is chromosomal non-disjunction, possibly from a polysomic complement. In at least two papers (Bever, I940 ; Stakman et al., 1943) basidia with $3:$ I segregations of supposedly unit factors are described without attentive remark. In yeast asci, a superficially similar behaviour has been interpreted in terms of cytoplasmic transmission (Spiegelman, 1946) or of gene-to-gene transfer (Lindegren and Lindegren, 1946). Hitherto, morphological characters have been used almost exclusively in studies on smuts. The biochemical mutations we shall discuss later may be more advantageous, and studies in this direction are in progress (Perkins and Ryan, unpub.).

Genetical phenomena in the higher basidiomycetes have been reviewed by Buller (1941 $a$; I94I $b$ ) and Kniep (1929).

A major obstacle to experimental work on Phycomycetes has been the difficulty of germinating zygospores produced in artificial crosses. On the other hand, many species are heterothallic and can be crossed at will. Perhaps the most interesting result to date of genetic work in the group is a discrepancy between genetic and cytological conclusions on the constitution of the zygospore in the Mucorales. According to most cytological studies (Cutter, 1942a; 1942b), zygospores are formed by fusion of two gametangia of opposite mating type. Many nuclei are present in each gametangium and many diploid zygote nuclei are formed. Subsequently each diploid nucleus undergoes a reduction-division. The germ mycelium issuing from the germinating zygospore should therefore be a heterokaryon comprising nuclei of many recombination types. These nuclei can be separated in subsequent sporulation.

In Phycomyces blakesleeanus, however, Burgeff (1915, 1928) analysed 
germ mycelia from zygospores heterozygous for three factors. No single zygospore yielded more than four mutually complementary classes of sporangiospores, although all of the eight possible classes were recovered from several zygospores together. In dihybrid crosses, he found approximately equal numbers of tetratype and ditype zygospores. He concluded that, contrary to his own cytological findings, only a single zygote contributes to the germ mycelium.

Zygospores of Mucor mucedo were subjected to a similar analysis by Köhler (1935), who concluded that only a single reduced nucleus survived since no genetic diversity was found among the issue of a single zygospore.

Genetic non-disjunction of sex-incompatibility factors has been reported by Burgeff (1915). While he could account for this in some sporangiospore cultures by heterokaryosis for incompatibility factors, he found some mycelia from which he was unable to segregate out the + and - components except from the zygospores they produced. He concluded, therefore, that these mycelia contained unreduced diploid nuclei heterozygous for the sex alleles. If these mycelia are truly diploid, they provide excellent material for the comparison of gene interactions within and across nuclear membranes.

Sporidinia grandis shows another sort of anomalous behaviour (Cutter, $1942 b$ ). The species is homothallic and produces superficially typical zygospores in pure culture. However, no cytological evidence could be found either of nuclear fusion or of meiosis.

The utility of genetic analysis in the solution of life-cycle problems is well illustrated by Emerson's work on Allomyces (194I). The species arbusculus and javanicus differ primarily in the arrangement of the gametangia. Although homothallic, the organisms can be crossed by the separation of male and female gametangia. By determining when segregation of the differential characters occurred, the time of reduction-divisions could be placed. It was shown that there was an alteration of diploid and haploid thalli " a most unusual state of affairs; extensively developed thalli with true, actively dividing diploid nuclei are probably not ordinarily formed by any other Phycomycetes."

The lower fungi exhibit a wide range of nuclear and life-cycle behaviour the potentialities of which have scarcely begun to be recognised. Aside from the studies already alluded to on the Mucorales and on Allomyces, and incidental observations on some Myxothallophyta (von Stosch, 1935), there has been no consideration of these forms as subjects of genetic study, although it is almost certain that it would reveal deviations of fundamental importance.

\section{(ii) Algae}

Genetic work on algæ has been overshadowed by the numerous contributions of F. Moewus ( $c f$. Buzzati-Traverso, 1947, p. $3^{8}$ ) on the chlamydomonads. Unfortunately, this "most remarkable series of 
studies in biochemical genetics..." (Beadle, 1945a) has been challenged in almost every detail (Smith, 1946 ; Sonneborn, 194 I ; Lwoff, 1947). To these comprehensive analyses, the present writer can add no informed comment. However, earlier work on algæ should not be overlooked, and Hartmann's review (1929) will be useful in planning experiments on this group.

Genetic recombination in bacteria and viruses will be dealt with separately because of the unique argument that must be used for its demonstration.

\section{MODES OF GENETIC VARIATION}

\section{(i) The Particulate Basis}

Genetic investigations of "perfect fungi" have clearly shown Mendelian corpuscular behaviour of genetic determinants; but there have been many attempts to formulate alternative systems for organisms, such as bacteria, less amenable to recombination analysis. Huxley wrote, speculatively, of bacteria that "the entire organism appears to function both as soma and germ plasm and evolution must be a matter of alteration in the reaction system as a whole" (1942). Similarly, Darlington (1939) refers to "genes which are still undifferentiated in viruses and bacteria." However, these statements are now probably convenient targets for controversy rather than expressions of their authors' present opinions.

The lack of outward differentiation of bacteria and viruses does give the appearance of holo-cellular propagation, and of an identity between direct transmission and inheritance. In binary fission, the substance of the cell is of course transmitted intact to the offspring. Inherited characters are fashioned out of this material. Rather than postulate an autonomous regulatory mechanism, therefore, many students have formulated the genetic system as the direct transmission of the material characters. Hinshelwood (1946), for example, has defined the bacterial cell as an extended fabric of enzymes with both auto- and hetero-catalytic properties. However, his admission that radiation induced mutations affecting enzymatic activity imply definite localisation of autocatalytic functions is difficult to distinguish from the abandonment of his definition.

The direct transmission theory may be disproved in several ways. First, bacteria are not so undifferentiated after all. In Salmonella, for example, they carry on their surfaces flagella containing serologically distinctive substances. When grown on agar containing phenol, they lose both flagella and specific antigens. A passage through ordinary medium suffices to restore these differentiated structures in their original form. The determinants of flagellar specificity are therefore transmitted in the absence of the flagella. The contrary result of a similar experiment, the inordinate delay in the restitution of a ntigens removed from the surface of Paramecium aurelia by antiserum 
and enzymes, has led Kimball (1947) to infer an autocatalytic role of the antigen itself.

The substrate of gene activity, the cell substance which is transmitted from parents to daughters, remains to obscure or delay the manifestation of genes, and it may take many cell generations for the gene fully to assert itself. When the cytoplasm has a certain capacity for self-propagation, phenotypic lag may be extended in time and give rise to the so-called Dauermodifications found particularly in Protozoa. Usually, such lags are of shorter duration and are described as instances of non-autonomous gene activity. In Penicillium, for example, a mycelium heterokaryotic for colour factors produces uniformly coloured uninucleate conidia. The genetic constitution of the conidium is not revealed until the next conidial generation (Pontecorvo, 1946).

The kinetics of gene action is most readily observed in the study of phenotypic lag. The time course of the development of the phenotype may be studied, as it has been in Protozoa, following genetic variation, or following the environmental suppression of gene activity ; for example, the inhibition of pigment formation in Serratia marcescens at high temperatures ( $c f$. Jordan et al., r 946 ), and the absence of gene-controlled enzymes in the absence of the corresponding substrates (Spiegelman, I946). Similar materials are mutants of Neurospora which show wild type expression under restricted $p \mathrm{H}$ and temperature conditions (MacElroy and Mitchell, r946).

Phenotypic lag and Dauermodification must be taken into account in constructing a formal definition for genetic variation. We are accustomed to regard genetic variations as qualitative changes in a self-reproducing substance. Accordingly, a genetic or heritable variation should be defined as a change of type which, after removal of the agent provoking the change, retains the capacity for indefinite propagation. When mutation or selection pressure is overwhelming, it may be difficult to demonstrate this capacity. Other techniques must then be developed to determine whether an induced modification is genetic.

The suitability of micro-organisms, especially bacteria, as materials for mutation study is attested by their increasing use (Luria, 1947b). Geneticists and bacteriologists alike have nevertheless shown a justifiable hesitation in accepting unanalysed genetic variations as gene mutations, although this is usually the most economical classification. For present purposes, a chromosomal gene is integrated with the multiplication of the nucleus or cell so that there is always a small determinate number of genes per nucleus, cell, or similar unit. We know from work on other organisms that there are several categories of genetic variation in addition to the mutation of chromosomal genes defined in this way. Some of these categories are listed in table 2, along with a précis of the diagnostic procedures that can be applied to " asexual " micro-organisms. 


\section{(ii) Chromosome Alteration}

Drosophila and maize have nothing to fear from the competition that any micro-organism will have to offer in the field of cytological analysis. However, favourable organisms such as Neurospora, in which the cytological detection of chromosomal rearrangements is feasible, provide material for the physiological effects of chromosome alteration. At least one mutation in Neurospora, albino-I " 4637 ," is associated with a reciprocal translocation (McClintock, I945). The reverse mutability of many Neurospora mutants proves only that the defects are not gross deletions, since phenotypic reversions of position effects have been reported in Drosophila (Kaufmann, I942).

In bacteria, it would be impossible to see even large rearrangements of such chromosomes as there may be. Structural changes might be detected in " sexual " species by their effect on crossing-over, but no aberrations were detected in $128 \mathrm{X}$-ray and mustard treated chromosomes of Escherichia coli thus tested (Lederberg, I947b). Whether complex genetic alterations, described by Luria (1946) as occurring too frequently to be accounted for coincidence, are chromosomal aberrations remains to be determined.

\section{(iii) Cytoplasmic Transmission}

The role of the cytoplasm in hereditary transmission is not difficult to verify in sexual organisms, especially if one parent contributes the bulk of the cytoplasm to the zygote. Anomalies in the distribution of chromosomes may, however, spuriously simulate extra-chromosomal heredity. Factual evidence to the contrary should therefore be offered in support of any cytoplasmic hypothesis.

In Paramecium, cytoplasmic heredity was proved pre-eminently by a correlation between the transfer of kappa, a killer factor, and a mode of conjugal association which permitted of the transfer of substantial amounts of cytoplasm (Sonneborn, 1946, 1947a). In the rust, Puccinia graminis, the cytoplasm was implicated by differences between reciprocal hybrids. The host range of an æciosporic clone was governed by the constitution of the æcial parent which contributes the bulk of the cytoplasm (see Johnson, I946).

Cytoplasmic transmission in yeast has been inferred by Spiegelman, Lindegren and Lindegren (I946). Tetrads of ascospores were found with a $3:$ I or $4: 0$ segregation of a fermentative character instead of the monofactorial expectation, $2: 2$. The exceptional spores were regarded as genic recessives masked by cytoplasmic units. However, their initial claim that the masked recessives could be distinguished from the genic dominants by the stability of the character to removal of its substrate was not confirmed in the Lindegrens' repetition of the experiments (1946). On the other hand, Spiegelman has published (I946) an extensive experimental support for cytoplasmic factors as mediators of gene action, if not in hereditary transmission. 
Lindegren and Lindegren (1946) have subsequently retracted his interpretation of exceptional ascospores as carriers of cytoplasmic factors. Faced with the paradox that the masked recessives were too stable in vegetative propagation to permit of only a small number of cytoplasmic units, and too unstable in crosses to permit of a very large number of these units, they resorted to an ingenious hypothesis of gene-to-gene transfer at meiosis. This suggestion is reminiscent of the Konversion theory adduced by Winkler (1932) and adopted by Zickler (1934) to explain anomalous $3:$ I asci in other fungi.

The cytoplasmic and the gene-transfer explanations are both open to criticism because they are based upon the unproven premise of regular chromosome transmission in yeast ascosporogenesis. Segregation from a polyploid or polysomic complement could also give the same pattern of irregular ratios. While the controversy attending the identification of the nucleus of the yeast cell (Nagel, 1946) shows the difficulty of unambiguous cytological work with this organism, genetic studies using linked factors could give an equally satisfactory decision.

Cytoplasmic transmission in clonal reproduction can be detected in several ways, none so rigorous as recombination analysis. In the first place, the dosage-response relationship for the inactivation of $n$ particles per cell by quantised agents such as X-rays is $p_{m}=\left(\mathrm{I}-e^{-k d}\right)^{n}$, where $p_{m}$ is the proportion of mutants (i.e. cells in which each of the $n$ genetic factors is changed or lost), $d$ the dose, and $n$ the number of factors. For $n=\mathrm{I}$, as in a haploid, $p_{m}=\mathrm{I}-e^{-k d}$. For small values of $p_{m}$, there is nearly a linear relationship between the dose and the proportion of mutants obtained. For higher values of $n$, however, the relationship is not at all linear. Instead one finds that there is a threshold value for the dose below which mutants are not produced at a significant rate. Preer (1947) has applied this technique to the enumeration of kappa in "killer" Paramecium, with results which are in good accord with independent estimates (Sonneborn, I946).

Quantitative studies on the induction of mutations by radiation in bacteria have been made by Demerec (1947) and Demerec and Latarjet (1946). The linear form of their dosage response curve is good evidence that the character studied (which was resistance to bacteriophage, to be discussed below) is controlled by chromosomal rather than cytoplasmic factors. As yet, no corresponding proof for plural cytoplasmic factors has been found for any bacterium. However, on the widely current assumption that intracellular viruses and plasmagenes may be closely related (Darlington, 1944), it would be pertinent to mention a report by Luria and Latarjet (1947) on the sterilisation of intracellular bacteriophage by radiation. They showed that phage particles could be inactivated by ultraviolet light after adsorption onto the cell. The disinfection of phage-infected bacteria was not directly demonstrated, but that it might occur and leave a 
viable cell free from phage can be inferred from the relative rates of inactivation of bacteria and of bacteriophage. If the rates are independent, a dose killing 99 per cent. of the bacteria would leave 90 per cent. of the survivors free of active phage, if there were 15 particles per cell at the time of irradiation. As in Preer's analysis, the non-linear disinfection curves would be clear-cut evidence of the multiplicity of the determinants, in this case the phage particles. However, dominant or suppressive mutations of a cytoplasmic factor would not behave in this way, but would follow a simple linear law.

The dissociability of the multiplication of cells and plasmagenes has been used by Preer in a brilliant enumeration of kappa in Paramecium (1946). He found that the cultivation of killer races under conditions of rapid proliferation resulted in the irreversible loss of kappa in a large proportion of individuals. The time course of the loss led to the conclusion that the cells might multiply more rapidly than kappa, resulting in a progressive dilution in the amount of kappa per cell. When only one or a few particles are left, a daughter cell of the next fission might have none at all, resulting in an irreversibly sensitive, non-killer individual. Extrapolation of the curve of loss to the beginning of the experiment allowed the enumeration of kappa in standard cultures of Paramecium. The estimate was approximately 256.

The success of this approach suggested to Sonneborn that other differential conditions might be found (Sonneborn et al., 1947). He found that kappa was inactivated at high temperatures. Enumeration of kappa using the kinetics of inactivation confirmed Preer's estimate. The calculations involved here are essentially the same as those already mentioned in connection with radiations.

In an attempt to discover cytoplasmic phenomena in the inheritance of bacteria, one could hardly do better than follow these leads and look for mutations occurring en masse in populations treated with heat, antiseptics, etc. Most reports of such changes to be found in the bacteriological literature cannot be credited because the likelihood that spontaneous mutants were simply selected to the point where they overgrew the population was ignored.

An additional method of examining the possible cytoplasmic basis of a genetic variation is provided by the formation and dissociation of heterokaryons. In many fungi, as we shall see, it is possible to mix the nuclei of distinct strains in a common cytoplasm. Lines derived from a single nucleus may be subsequently recovered. If a genetic variant can be recovered from a heterokaryon with wild type or other mutant nuclei, localisation of the variation in the nucleus is implied. While no application of this procedure to bacteria is in sight, it may be useful in dealing with variation in Penicillium and other imperfect fungi. To date, such tests have proven uniformly negative; that is, no demonstration of cytoplasmic inheritance in a filamentous fungus has been presented. 


\section{(iv) Heterokaryosis}

Heterokaryosis, or genetic diversity among nuclei in a cœnocyte, may behave like a cytoplasmic system in mutational behaviour. The units are not, however, determinants of single characters or independent plasmagenes : they are whole genomes packed in discrete nuclei.

A spurious mass mutation may result from the spontaneous or induced segregation of the nuclear components of a heterokaryon. The spontaneous dissociation of heterokaryons has been noted by Pontecorvo (1946) in Penicillium and Aspergillus and by L. (unpub.) in interspecific Neurospora combinations. It would have been described as a persistently recurring mutation had not the heterokaryotic system been the result of design. The term "dual phenomenon" has been used by mycologists to describe the results of heterokaryotic segregation in many fungi (Hansen, 1938).

X-ray treatment of Neurospora tetrasperma ascospores induces dissociation (Uber and Goddard, I934; L. unpub.). The spores have four nuclei, two of them carrying each mating type allele. They normally germinate, therefore, into sexually self-fertile, heterokaryotic, mycelia. A large proportion of irradiated spores, however, are selfsterile, owing presumably to their having become homokaryotic. Hence, the "inactivation" of two nuclei carrying one of the mating type alleles may be inferred. Sterilisation of ascospores is of course not linearly proportional to the X-ray dose. The experiment illustrates an induced dissociation which simulates a mass mutation from fertility to sterility.

To ensure that a mutation induced by a given treatment is not a spurious unmasking of variability concealed in the heterokaryotic condition, the origin of treated clones from single nuclei must be verified. In many organisms, e.g. Neurospora crassa, the ascospores can be shown to originate from single nuclei, both by genetic and cytological methods. In others, evidence for at least initial homokaryosis can be adduced by obtaining lines expressing a recessive mutation, since the manifestation of recessive mutations, such as growth factor deficiencies, speaks for the absence of nuclei carrying the corresponding dominant allele. From the premise that mutations occur sporadically, the conclusion is drawn that such recessive lines probably originate from a single mutated nucleus. Even when they have gone to great pains to ensure the initial purity of their lines, a surprising number of workers have then forgotten that spontaneous mutations will accumulate anew, especially in the characteristically large populations of micro-organisms. The discussion of this problem will be continued in relation to criteria for mutagenesis.

The synthesis of heterokaryons is probably of great importance in the natural economy of fungi. For example, single-spore homokaryotic lines of smuts are unable to maintain a parasitic invasion of their host. Hyphæ of appropriate genetic (mating-type) relation- 
ships regularly fuse to form the virulent dikaryotic phase, which constitutes the larger part of the life cycle.

Heterokaryon formation should never confuse a student of variation. It needs to be distinguished only from Mendelian recombination for it can occur only in a population already diverse. Heterokaryons provide unique material for the analysis of gene interaction, as exemplified by the work of Dodge (1942) and Beadle and Coonradt (1944) in Neurospora, and Powers (1943) on double animals of Euplotes.

Unfortunately, material in which the geneticist can compare the behaviour of alleles, collected in the same diploid nucleus, and distributed among different haploid nuclei in a heterokaryon, is rather rare. As has already been mentioned, however, exceptional hermaphroditic or solo-pathogenic lines of Phycomyces and Ustilago, which are probably diplogenic, have been secured. In these same species it is quite easy to secure heterokaryon synthesis.

On the basis of very few experiments, it has been concluded that gene interactions in heterokaryons are similar to those in diploid heterozygotes. This has led to the transfer of the terminology of "dorninant" and "recessive" to heterokaryons (Beadle and Coonradt, I944). In the simple additive systems which have so far been reported, no confusion can result. Exceptions have been noticed to the simple rule that biochemical mutations should be recessive in heterokaryons, but these may be interpreted in terms of the single parameter of gene efficiency. On the other hand, it should be demonstrated that an inefficient combination is actually heterokaryotic before conclusions as to gene efficiency are drawn. The suggestion that genetic factors control the capacity for mycelial fusion adds particular weight to this consideration.

In biochemical work on Neurospora, the formation of efficient heterokaryons has been a useful criterion for distinguishing physiologically distinct mutants with a similar phenotype. In all the cases so far studied, strains which yield effective heterokaryons have been genetically distinct in breeding tests. So long as the perils of confusing the gene as a physiological unit with the gene of crossing-over and with the gene of sporadic mutation are kept in mind, the formation of efficient heterokaryons is a very useful tool for the identification of alleles in imperfect fungi.

\section{(v) Polyploidy}

Direct proof of polyploidy, or polysomy, which will not be distinguished in this discussion, has been given in a micro-organism only by Chen's cytological studies on Paramecium bursaria (1940). The irregularity in time of reduction in Phycomyces is not a true polyploidisation, since the doubling of "ploidy" does not persist through a sexual generation. The diplogenic lines undergo, instead, reduction without additional nuclear fusion.

Despite the hypothetical nature of any discussion of its role in 
microbial variation, polyploidy must be attended to, first, because it has been suggested (on very dubious grounds) in various fungi and, secondly, because of its importance in the genetics and evolution of higher plants (Darlington, r939).

The influence on yeast morphology of various chemicals has been studied by several investigators. The chemicals used include camphor and its derivatives (Bauch, I94I ; Levan, I947 ; Subramanian, I945 ; Thomas, I945), acenaphthene (Thaysen and Morris, I943), and various carcinogens, reviewed by Tatum (1947). The camphor induced forms have been claimed to be polyploid on uncertain grounds.

Sansome has reported (I946) the production of gigas strains of Penicillium by the use of camphor. By analogy with the larger pollen grains of polyploid phanerogams, she suggests that Penicillium gigas is diploid. The promised genetic and cytological investigation has not yet been published.

In a sexual organism, polyploidy is verified by simple breeding tests. These consist mainly of disturbed segregation ratios, and for an organism ordinarily haploid, of the capacity for heterozygosity at a locus, normally denied it. The appearance of a recessive phenotype in a cross between two dominant nuclei allows a prima facie case for the di- or polyploid status of one of the parents. The possible application of this principle to yeast and smut segregations has already been pointed out.

The detection and verification of polyploidy in the asexual organism, as with so many other genetic problems, must be less direct and therefore less certain. Aside from mitotic chromosome counts which are impossible in some and unreliable in most microbes, the only basis is the modified mutational behaviour of the diploidised organism. The diploid phenotype may be expected to be stable in the face of recessive mutations since they would be masked by their unmutated, dominant opposite partners. The Neurospora heterokaryon work, as already mentioned, implies that mutations involving the loss of a biochemical capacity will be recessive. On these premises, the inability of a derived strain to manifest biochemical mutations, in contrast with the appearance of mutants in the parent strain, would strongly favour the polyploid status of the former. Such obvious pitfalls as the similar masking of mutations by cytoplasmic factors or by other nuclei in a multinucleate cell must, of course, be considered. The test is perhaps less conclusive when applied to organisms as found in nature, than where comparisons can be made with the original untreated strain in experimental polyploidisation, but the failure, despite persistent efforts, to obtain biochemical mutants in Proteus vulgaris (Beam, C. A., and Tatum, E. L., unpub.) and Phytomonas tumefaciens (Burkholder, P. R., unpub.) suggests the reduplication of the genetic units of these organisms.

Experiments I have made along these lines to produce stable diploids of Escherichia coli have so far proved unsuccessful. Gell 
suspensions were treated with camphor or acenaphthene in nutrient media. Lines derived from single colonies were then tested for their ability to mutate to resistance to sodium chloroacetate, a character selected because it is associated with deficiencies in the metabolism of pyruvic acid. In addition, mutability to this character is rather easily determined. Since it has a rational basis, the method should eventually be successful, or else the fallacy be revealed.

The induction of polyploidy in bacteria has special interest, since it may open up the hitherto unrealised possibility of cytogenetic analysis. It might equally well be applied to organisms like yeast whose chromosomes have yet to be indisputably identified.

\section{(vi) Autogamic Phenomena}

Autogamy cannot produce variation in a haplont. Nevertheless, the sexual phase of certain haplontic yeasts (e.g. Nadsonia) is essentially autogamic and supposedly fortuitous. In diplonts, on the other hand, autogamy may play a substantial role in the origin of new genotypes. It is especially prevalent in the ciliate protozoa (Sonneborn, I947a). In Paramecium, a tetrad of haploid nuclei is produced by reductiondivision of the diploid micronucleus. Subsequently, twin mitotic progeny of one reduced nucleus fuse and give a homozygous animal, while the other nuclei degenerate. The result is that loci originally heterozygous are made homozygous for one allele, for which one is left to chance. In this way, a recessive allele whose manifestation is masked in the diploid heterozygote has a $5^{\circ}$ per cent. chance of expression after autogamy.

This process has been repeatedly proposed as the basis of bacterial variations, particularly the lactose-fermenting mutants of Escherichia coli mutabile (Stewart, 1943). But this theory is not supported by the independent occurrence of variations for the fermentation of different sugars ( $c f$. Kristensen, 1944).

Like autogamy, non-disjunction of determinants has been proposed as the mechanism of bacterial variation (Parr and Simpson, I940; Reed, 1933). This theory likewise predicts the concurrence of two new genotypes, i.e. $\mathrm{a} \rightarrow \mathrm{aa}$ and no-a (rather than $\mathrm{Aa} \rightarrow \mathrm{AA}$ and aa), a prediction which has never been confirmed.

\section{(vii) Heterogamic Phenomena}

The significance of gene recombination as a source of variation in higher forms is too familiar to require discussion. However, it can only be effective in a genetically heterogeneous population. Like heterokaryosis, therefore, it cannot occasion confusion in the analysis of genetic changes in a homogeneous population. Unfortunately, one cannot always be sure of the genetic homogeneity of a population whose units have an unknown genetic structure. The proof of the occurrence of recombination in supposedly asexual organisms is discussed later. 


\section{(viii) Gene Mutation}

Among higher organisms, gene mutation refers to a change associated with a point on a chromosome. Methodologically, it is the extreme of alterations of progressively smaller segments of the chromosome. Both kinds of localised changes are studied by their segregation and recombination at meiosis correlated with cytological examination.

Gene mutations are of special interest insofar as they are changes in the fundamental hereditary particle, and from this point of view their localisation in the chromosome is of secondary interest. It may be, for example, that the plastogene is complex. In algæ which normally contain but one chloroplast per cell (Lwoff, I943), the chloroplast would then be homologous to the chromosome, and plastogene mutations comparable to gene mutations. Similarly, qualitative changes in plasmagenes have the same significance as gene mutations.

Without the help of breeding analysis, a hereditary change cannot certainly be classified as a gene mutation. In assaying the significance of such changes, be they spontaneous or induced, it is important to classify them as changes in number or distribution of particles (polyploidy, heterokaryosis, autogamy, plasmagene segregation, autogamy and heterogamy) as opposed to changes in kind (mutation, chromosome aberration, plasmagene mutation). We have just reviewed some of the techniques which can be applied to this problem. It is apparent that only a very detailed study of the mutational behaviour of an asexual form can take the place of a simple breeding experiment.

In the following discussion, "mutation" will be used somewhat indiscriminately with the understanding that each case will ultimately have to be examined on its own merits.

\section{(ix) Enzymatic Adaptation and Antibody Production}

Neither enzymatic nor immunological adaptation is a true genetic change. They are not changes transmissible in the absence of the evocative stimulus. However, the production of enzymes and antibodies is believed to involve the activity of a generating particle which may be identified. with the gene or immediate gene products such as plasmagenes (Spiegelman, I946 ; McIlwain, I946).

The mechanisms (Spiegelman, I946) which have been proposed for enzymatic adaptation, involving proliferation of more or less autonomous plasmagenes, are an intracellular counterpart of selection and competitive growth of cell populations, and are even more strikingly analogous to these phenomena in nuclear populations in heterokaryons. At none of these levels-cells, nuclei, or plasmageneshas more than a start been made toward working out the nutritional and antagonistic relationships. For technical reasons, cell and nuclear populations are more readily studied than plasmagene aggregations, but their bearing on each other should not be forgotten. 
That specific antibody production in animals is analogous to enzymatic adaptation has been often commented. In both, a specific protein is generated which reacts with the provoking substrate. Unfortunately, the animal body has proved to be too complex for the direct analysis of the kinetics and cellular transmissibility of antibody formation. A likely solution to this difficulty is available in a report by Fox and Ward (1946), that yeast produces specific precipitins to conjugated proteins added to the culture media.

TABLE 2

The diagnosis of genetic variations in asexual forms (or without the use of breeding tests)

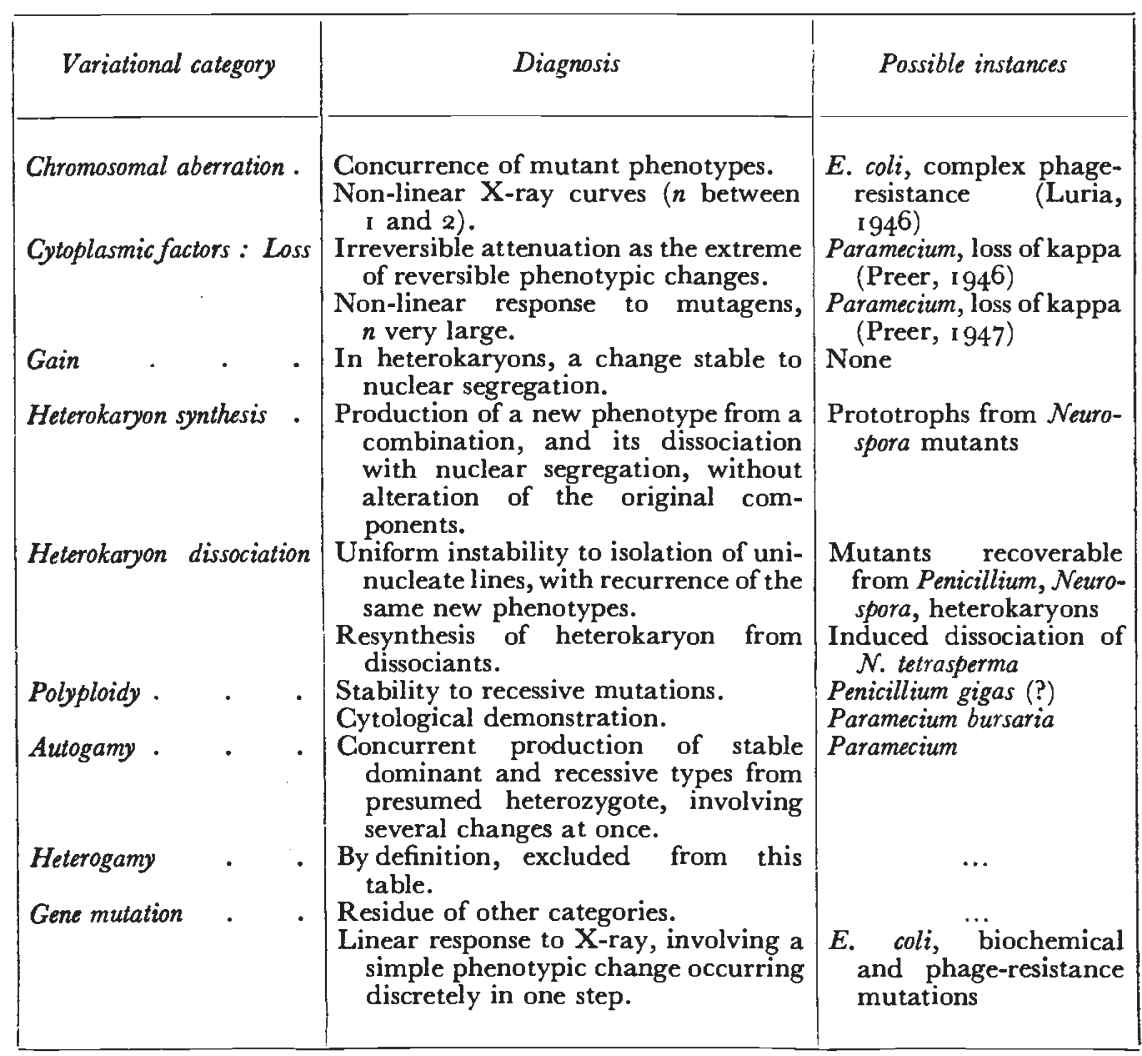

\section{MUTAGENESIS, OR THE INDUCTION OF MUTATIONS}

The use of agents inducing qualitative changes in genes is almost the only direct attack on their nature. Unfortunately many experiments dealing with mutagenesis have been poorly designed, failing to take account of all sources of error. For this reason, particular attention will be paid here to the design of experiments and the main sources of error in the study of mutagenic agents. 
In many cases, the procedure used to estimate the number of mutants in a population is a selective one. A deleterious agent such as a drug or a bacterial virus is applied to suppress the non-mutants en masse and permits the development only of mutants which are adapted to the agent. Provided the number of mutants is not negligible, the result is a new population, albeit decimated, adapted to the agent. The adaptive features of this process have led most bacteriologists to the Lamarckian sort of belief that the mutations are somehow specifically induced by the agent which was used to select them. This is, of course, contradictory to the conclusions from studies on higher forms.

The problem is not readily solved by any straightforward means. In most instances the only way to obtain the mutants is to apply the selective, supposedly mutagenic agent. A number of lines of evidence have been developed, however, which contradict direct induction of adaptive mutations. They consist chiefly of showing that there is no direct relationship between the experimental agent and the time of appearance (Kristensen, 1944), or statistical distribution of the number (Luria and Delbrück, r 943) of mutants. The problem has been discussed in detail by Luria $(1947 b)$. For the future it is piously hoped that any claims of specifically directed adaptive mutations will be supported by critical consideration of alternative explanations, especially the selection of previously occurring spontaneous mutants.

There are at least two ways in which apparent mutagenic activity may in fact be spurious. First, the effect of the mutagen may be to unmask previously concealed variability, as has been mentioned with respect to heterokaryons or, even less subtly, by leaving single cells rather than cell clumps to survive its toxic action. Secondly, it may enhance the proportions of mutant cells by selective actioneither in relative killing or relative growth.

The possibility that variability may be concealed can only mean that the method used to estimate the number of mutant nuclei is at fault. The most refined test of a method in chemical analytical work is quantitative recovery of known amounts of the added substance. Likewise, the best empirical justification of a mutant "assay" method, selective or otherwise, is to show that the addition to a population of a known number or proportion of the mutants in question leads to a corresponding increase in the assay of that population. The recovery test should, of course, be run under conditions closely approximating those of the experiment. In some cases this is not entirely feasible - e.g. where introducing nuclei into a heterokaryon is required.

Usually, the concealment of variability is due to the origin in the controls of colonies or clones from more than a single cell or nucleus. On this point, tests on the segregation of mixed populations are to be preferred to purely cytological evidence. Conclusions of a 
satisfactory qualitative nature can be drawn from such experiments, but the possibility of deviations in nuclear ratios in the formation of conidiospores, or the fertilisation of ascogonia, cannot be excluded. Where possible, recovery tests should therefore be made. For example, Stahmann and Stauffer (1947) have reported on the induction of mutations in Penicillium by a nitrogen-mustard compound. Nearly half the survivors of a treatment which reduced the colony count to 2.6 per cent. of its original value were scored as mutants, as compared with mutant frequency of 0.1 per cent. in the untreated material. Other observations corroborate this report of mutagenic activity of mustards, but the considerations discussed earlier may affect the accuracy with which the dependence of mutations induced upon the dosage can be measured. The proof that an effect has not been selective may depend on accurate and valid measurements of this sort. It should be noted that a plot of the log mutants against dose (as measured by time of treatment) is far from linear and shows a distinct early "plateau" or sub-threshold region. This may be due to a "multiple-hit" effect or to the time required for penetration of mustard into the cell.

Granted that a population of verifiable single nuclei can be obtained, it is almost inevitable that a small proportion of such nuclei will be spontaneous mutants. It is almost equally inevitable, probably because some genes are indispensable for the vital economy, that a non-specific mutagen will be toxic. How, then, can one discriminate preferential survival of pre-existing mutants in a decimated population from the induction of new mutations by the experimental agent? There are two alternatives, to show : (a) that an absolute preference for the pre-existing mutants cannot account for their numbers, either by the use of populations demonstrably free from the mutants to begin with, or by the demonstration of an increase in the total absolute numbers of mutants despite the reduction in the population; and $(b)$ that mutants are not selectively favoured by the treatment.

The first method is no more valid than the assay procedure used to enumerate the mutants, and although it is perhaps the more determinate of the methods it must be used with great caution. The crucial premise of this method, the total absence of spontaneous mutants, is indeed rarely fulfilled, but is prepostulated in the pneumococcus transformation experiments (McCarty, I946). An increase in the absolute numbers of mutants has been cited as evidence of mutagenic activity by several authors (Giles and Lederberg, I948; Stahmann and Stauffer, 1947; Witkin, I947), but only one has also reported recovery experiments justifying her mutant assay method.

The number of spontaneous mutants and the toxicity of the mutagenic agent impose severe limitations on the applicability of this method. From idealised single-hit assumptions on the kinetics 
of killing and mutation, it can be deduced that the absolute number of induced mutants reaches a maximum when there are $1 / \mathrm{e}$ or about 37 per cent. survivors. There can be an absolute increase only if the number of mutants induced by this mild treatment more than compensates for the 63 per cent. of the spontaneous mutants which are lost.

Selection has usually been considered, if at all, in terms of method (b). That is, the effects of an agent have been measured on populations of the wild type and of the mutant separately. The fallacy here is that in any experiment it is not the pure but a mixed population which is treated, and there are now only too many illustrations of microbial interactions which remain undisclosed under examination of the isolated cultures (Luria, 1946 ; Ryan, 1946b).

The addition to the untreated population of a known number of mutants is preferable, especially an assortment obtained from a previous experimental run. This mixture is then subjected to the possible selective effect of the mutagen. Increasing the initial proportion of mutants in this way should exaggerate any selective effect but, if anything, should only diminish a mutagenic. effect by reducing the number of non-mutants available. In most cases the fraction of mutants found, even after treatment, is small, so that mixtures in small integral ratios of mutant to non-mutant should be relatively invariant to mutation, but responsive to selection. Such experiments should be run with a variety of initial ratios of mutant to non-mutant to ensure that the equilibrium mixture, if there is one, is not inadvertently the one tested. Of course, even this procedure is open to the objection that the conditions of the test for mutagenesis, namely a very small initial fraction of mutants, are not met, but it probably represents the best experiment that can be constructed. This technique has been applied in very beautiful and adequate fashion by Witkin $(1947 b)$ in demonstrating the mutagenic effects of various reagents on $E$. coli.

The ideal experiment which has just been discussed analyses a non-proliferating population. The continuing growth of a culture during a mutagenic treatment introduces numerous complications in the analysis. In particular, the parameter of number of mutants becomes no longer a function solely of the number of mutations, but of their multiplication potential, in terms both of selection and of their early or late occurrence in the growth of the culture. On the latter basis alone, the distribution of spontaneous mutants in replicate cultures has been shown to be highly abnormal (Luria and Delbrück, 1943), a factor too often neglected in the statistical comparisons of treated and untreated material. Unfortunately a greater or lesser period of multiplication following treatment may be essential for the manifestation of the mutations induced (Demerec and Latarjet, 1946; Tatum, 1946). The period of incubation after treatment should be as short as possible, and should be subjected to the most 
careful scrutiny in experiments designed to yield quantitative information. The same tests which were suggested for the elimination of the selective factor during treatment can well be applied here.

In the now classical work on mutagenesis in higher organisms, it has not been practicable to apply criteria for the minimisation of possible selective interferences. In Drosophila, for example, it is not readily determinable what fraction of sperms has survived an irradiation, and therefore it is not known what possibility there is that induced mutations were somehow selected for! It could be shown, however, from disturbances in genetic ratios that mutants were disfavoured rather than favoured in competition with wild-type forms. A similar argument has been applied to justify certain claims for mutagenesis in micro-organisms (Gray and Tatum, 1944; Tatum, I945 and 1946). Provided that the question of concealed variability is dealt with, the production of a wide variety of mutant genotypes after a treatment can be regarded as provisional evidence of mutagenic activity.

To summarise, the method for estimating the proportion of mutants should be justified experimentally. Selective effects of proposed mutagens should be ruled out by recovery experiments involving mixed cultures. If growth takes place, similar recovery experiments are called for, and the abnormal statistics taken into account. The desirability both of quantitative studies on the mutation-dose relationship, and of the isolation of a variety of mutant types is obvious. Finally, further characterisation of the mutants obtained, along the lines of table 2, should not be neglected.

It may seem that these criteria are over-cautious or hypercritical. They are not vitally important in experiments with familiar mutagens such as X-rays, ultra-violet light, and the now familiar mustard compounds. Reports have also appeared, however, suggesting mutagenic activity of antiserum, carcinogens (Tatum, 1946), nuclear dyes (Witkin, 1947b), nitrous acid (Steinberg and Thom, 1942), specific transforming factors and irradiated broth. These reports are too pertinent to our conceptions of the nature of the gene and of the mutation process for them to be accepted without an exceedingly critical examination.

Emerson (1944) has reported the induction of mutations by antiserum in Neurospora which, if substantiated, would justify a farreaching fundamental basis for biological specificity: the surface properties of genes, plasmagenes, antigens, enzymes, and antibodies ! Ascospores isolated from crosses with treated conidia had more mutants than spores derived from untreated conidia; but there are too many points where selection could operate-e.g. in competition of nuclei for traversing the receptive hypha and fertilising the ascogonium-for the procedure to be beyond suspicion.

That heritable changes, other than mutations in chromosomal genes, may be induced by antiserum has been demonstrated by 
Sonneborn in Paramecium (1947b). In this material he distinguished four serological types of animal, the determination of which was proven to be cytoplasmic. Change of type occurred spontaneously on the order of once per 500 fissions. Treatment with critical levels of homologous antiserum resulted in the alteration of type of 20-90 per cent. of the animals, with very little killing. Further serological analysis suggested that none of the types was antigenically pure, and that the effect of the antiserum was to affect the predominance of one cytoplasmic determinant over the others. In a sense, this is an intracellular selection phenomenon affecting the survival of plasmagenes.

Stone, Wyss, and Haas (I947) have reported on the induction of mutants of Staphylococcus aureus resistant to penicillin or streptomycin by growth in nutrient broth which had previously been irradiated with ultra-violet light. This report has obvious implications for the direct or indirect mechanism of radiation-induced mutations in all organisms.

Unfortunately, the possibility of selection in favour of mutants by the irradiated broth was not disposed of in this publication, nor were recovery experiments reported which might validate their assay method. Dr Stone tells me, however, that they have later performed some of the requisite selection experiments and concluded that there was no competition between sensitive and resistant types either in normal or in irradiated broth. This conclusion may be at variance with Luria's statement (I946) that "viable counts of a penicillinresistant mutant in mixed culture with the parent strain began to fall long before the end of the growth phase-for separate cultures of either strain."

The probable mechanism of the action of ultra-violet light in these experiments is suggested by a similar indirect action of hydrogen peroxide. Broth treated with hydrogen peroxide was as active as irradiated broth in producing drug-resistant mutants (Wyss, Stone and Clark, 1947). These authors have suggested further that both radiations and hydrogen peroxide may produce modified metabolites which when incorporated into certain genes lead to their inactivation. In support of this suggestion they have claimed that the treatment of specific, but unspecified, components of the culture medium resulted in the induction of specific mutations. Further work, however, has not supported this contention (Stone, unpub.).

\section{MUTAGENS}

Radiations, which have been so effectively used for the production of mutations in higher organisms, have proved equally efficacious in micro-organisms. X-rays and ultra-violet light have proven to be useful laboratory expedients for the production of mutations. But, so far, quantitative studies designed to elucidate the mechanism of 
radiative action are still in their infancy. The outstanding exception lies in recent work on the induction of virus-resistant mutations in $E$. coli, and on the occurrence of mutants of the same bacterium which display enhanced resistance to the lethal effects of radiations.

Demerec and Latarjet (1946) irradiated suspensions of $E$. coli which were then spread thinly over the surface of agar plates. Immediately, or at stated times after the irradiation, bacteriophage was sprayed on the plates, resulting in the lysis of all sensitive cells before the lapse of another cell generation. Unfortunately, no experiments have been published showing that in mixed cultures, sensitive and resistant bacteria are sterilised by radiations at the same rate. (Such experiments have, however, been performed. Witkin, E. M., unpub.) The rate at which mutations are induced is apparently not quite high enough in proportion to the lethal effects to lead to an increase in the absolute assay of mutants in the population. It was found however that, as between radiation-sensitive and resistant strains, the yield is proportional not to the killing but to the dose measured in physical units.

It would thus seem that selection is very improbable as the effective mechanism of apparent mutagenic action of radiations. The same consideration applies also to the possibility that latent variability plays a predominant role-at least in the production of mutants detectable immediately after irradiation. This last qualification is introduced because it was found that the rate of appearance of mutants remains higher in a previously irradiated population than in untreated cultures. Thus, the final effects of the radiation, the occurrence of detected mutants may be somehow delayed for a number of cell generations.

Demerec (1946) has offered a number of possible interpretations for delayed manifestation. In the first place, genic variation may not be able to show up immediately due to cytoplasmic lag. Secondly, the expression of the mutation may be masked by the presence in the same cell of dominant allelomorphs; not until the segregation of the mutant and unmutated genes in subsequent divisions (of nuclei, chromatids, or cytoplasmic factors?) would the mutation be unmasked. Thirdly, the effect of radiation might be to increase the instability of the gene, so that it would exhibit a high mutation rate until it finally "settled down" to a stable mutant or non-mutant configuration. For the last suggestion, there exists the analogy of iso-alleles in Drosophila (Timoféeff-Ressovsky, I937), maize (Rhoades, I94I), and probably bacteria (Lederberg, $1947 b$ ) which differ primarily in their rate of mutation.

The linear relationship between dose and mutation in the X-ray experiments implies that the immediate mutants are produced by single hits. The response to ultra-violet light, however, is considerably more complex and remains to be clarified. A most interesting feature in the comparison of ultra-violet and X-ray effects is that while 
$\mathrm{X}$-rays may exhibit a ratio of ultimate to immediate mutations of about I00: I, this ratio may be as high as $10,000:$ I with ultra-violet. This discrepancy is consistent with the interpretation of delayed effect as the chemical instability of the gene.

An analysis of mutation production by $\mathrm{X}$-rays and ultra-violet light showed that the former were far more efficient for a given amount of energy absorbed, but that they had a far higher level of killing for a given yield of mutants.

Quantitative studies on the production of morphological " mutations" by the irradiation of spores of a number of fungi have been described by Hollaender and his collaborators (1941 ; 1946). In general, it was shown that the production of mutants increased with increasing doses of ultra-violet light, reaching a plateau and falling off with further increases. The decline could be eliminated by suspending the spores in salt solutions for several days after irradiation. It was concluded that the mutated cells were more fragile to subsequent treatment, and that the salt solution allowed their recovery.

In a study of efficiency of mutation production at various wave lengths, efficiency peaks were found at $2280 \AA$ and at $2650 \AA$, the latter corresponding to the absorption peak of nucleic acid. Mutations were not produced at higher wave lengths, although some toxic activity remained. It was concluded that the mutagenic activity of ultra-violet light is associated with the absorption of energy by nucleic acids.

Mutations involving genes for biosynthetic processes have been reported to occur following X-rays or ultra-violet irradiation in Neurospora crassa (Beadle and Tatum, I945), Absidia glauca (Giles, 1947), Penicillium (Bonner, I946b), Ophiostoma (Fries, I947), among fungi, and in Escherichia coli (Gray and Tatum, I944; Tatum, I946), Acetobacter melanogenum (Gray and Tatum, 1944), Aerobacter aerogenes (Devi et al., 1947), and Bacillus subtilis (Burkholder and Giles, 1947). While critical proof of the mutagenic activity of radiations is for the most part lacking-chiefly in connection with the unmasking of latent variations, or in the less likely contingency of selective preferences favouring the survival of the mutants under the lethal action of the radiations-it appears very likely that radiations can increase the proportion of biochemical mutants from a variable spontaneous frequency of perhaps $0 \cdot 1-0 \cdot 2$ per cent. to a value of I-6 per cent. The conditions of production, the characteristics of mutants, and findings suggestive of delayed effects, corroborating Demerec and Latarjet, have been reviewed by Tatum (1946).

Although the mechanisms involved have by no means been elucidated, it is recommended that for the practical production of mutants by irradiation the treated populations should be incubated for a few cell-generations to allow the full manifestation of delayed effects. Failure to observe this precaution may have been a factor 
in Grainger's inability to isolate mutants of Eberthella typhosa from X-rayed suspensions (Grainger, 1947).

Following the reports of Auerbach, Robson and Carr (1947) on the mutagenic activity for Drosophila of mustard gas, several investigators have tested this compound and the homologous nitrogenmustards for mutagenic activity on micro-organisms. Horowitz and others (1946) treated Neurospora conidia with gaseous mustard, and after suspending them in sterile water, applied the treated conidia to receptive hyphæ of opposite mating type. On the assumption that the probability that a conidial nucleus will succeed in fertilising the ascogonium is independent of its genetic constitution, the $f-I$ ascospores measure the genetic constitution of the conidial nuclear population, the treated genes being diluted by an equal number of untreated genes contributed by the ascogonial parent. On this basis, the finding that 3.8 per cent. of the spores isolated from the treated series were biochemical mutants of a variety of types indicates that twice $3 \cdot 8$, or $7 \cdot 6$ per cent. of the conidial nuclei carried mutant genes, as compared to 0.26 per cent. in the control series.

Similar findings have been made by Tatum (1947) in bacteria, and in Neurospora crassa (Bonner, 1946a; MacElroy et al., 1947) using nitrogen-mustard, or di- $\beta$-chloroethyl-methylamine. In Neurospora, mutations were found in colonies obtained from treated microconidia, as well as in cultures of $f-I$ ascospores. Numerous mutants have also been obtained in haploid cultures of Saccharomyces treated with nitrogen-mustard by Tatum and Reaume (unpub.). Although detailed studies are still in progress, there has been no indication thus far that nitrogen-mustard differs from X-rays in the types of mutations induced. Delayed action of mustard compounds, comparable with that indicated by Auerbach, Robson and Carr has not been studied yet.

Recent studies by Witkin have revealed distinct mutagenic activity of a number of hitherto unsuspected compounds (1947b). Sodium desoxycholate was found to increase the proportions of virus-resistant mutants in washed suspensions of $E$. coli. Adequate precautions to rule out selective effects were taken by demonstrating that the composition of a mixed population of mutant and non-mutant bacteria was invariant under the toxic action of the desoxycholate. These same controls also constituted recovery experiments guaranteeing the procedure for assaying the number of mutants. Similar experiments showed that the dye pyronin was also active, although erratically so. Mutagenic activity was also found for proflavin, but not for methyl green. That the action of many of these agents may be indirect is suggested by recent reports from the same laboratory (Demerec, 1947) assigning mutagenic activity to several alkaloids, carcinogenic hydrocarbons and azo dyes, and mirabile dictu, common salt. The mutagenic activity of certain carcinogens is confirmed by their activity on Neurospora (Tatum, 1947). Many mycologists, notably Steinberg and 
Thom (1942) have observed morphological mutants of fungi occurring on various inhibitory media, into which such substances as arsenic, heavy metals, dyes, and nitrous acid are incorporated. Until the contingency of selection of spontaneous mutants has been disposed of, the direct mutagenic activity of these agents cannot be affirmed.

\section{MATERIALS FOR MUTATION STUDY : MUTANT CHARACTERS}

A wide range of characters subject to mutation is available to the microbiologist. Since, for obvious reasons, the clone rather than the cellular individual is the unit of phenotypic classification, most of the available mutant characters involve biochemical activities, instead of changes of form like those of higher organisms. We may now try to classify various mutational types likely to be useful in genetic and physiological analysis.

Nutritional or biochemical mutants, first studied intensively in Neurospora by Beadle and Tatum, have probably contributed more to the clarification of the role of genes in inheritance, both of microand macro-organisms, than any other type of mutation in recent years. They are characterised by their inability to synthesise essential constituents of their protoplasm, as revealed by their failure to grow in media lacking such constituents. The mutation presumably consists in blocking the activity of specific enzymes, although this has been directly established only in a few favourable instances. Alternatively it may be that the normal allelomorph imparts a particular specificity to an enzyme.

Workers in the field have, by and large, adopted the simplest formulation of the relation between gene and enzyme, namely the one-to-one concept. In a discussion of Bonner's review (r946a) of Neurospora, Delbrück ( $1946 b$ ) has outlined the type of experimental evidence on which proof of the one-to-one relation would have to be based. To support the one gene per enzyme part of the hypothesis, all mutations affecting a given enzyme must turn out to involve the "same gene," i.e. be allelic. Conversely, a given allelic series must be found to affect but a single enzyme.

The fitting of available Neurospora data to these tests is hindered primarily by our ignorance of the enzymatic mechanisms involved in most syntheses. Such knowledge is essential to determine whether a single enzyme has been affected by gene mutations. In at least one case a pleiotropic mutation, leading to a complex nutritional requirement for isoleucine and valine, has been shown to be explicable on the basis of a single, simple biochemical block (Bonner, 1946a). There is a temptation to extend this interpretation to other complex effects (Tatum and Bell, I946), but that merely begs the question. Be that as it may, no clear-cut contradiction of the one-to-one theory has resulted from experiments on Neurospora.

Certain objections to the theory cannot be reduced, however. 
They rest primarily on the definition of the gene. Many workers have pointed out that the several definitions of the genetic unitmutational, recombinational, physiological, and material-are not always congruous. The interaction of certain members of allelic series in Drosophila to yield phenotypes which are more normal than either allele homozygously, as Mather has pointed out (1946), speaks for the mutational separability of distinct physiological activities of the gene. Such cases have not yet been discovered in Neurospora, but they could presumably be detected by heterokaryotic vigour of allelic compounds. The extent to which the various ultimate units of genetics will continue to coincide remains to be seen.

If one accepts the one-to-one concept provisionally, the genotypic homology of similar biochemical mutations in diverse organisms is implied. It is perhaps the only situation where it is possible to argue from phenotype to genotype. An additional test for "physiological allelism" is available for biochemical mutants of bacteria, namely, syntrophism. In $E$. coli, it has been found that different biochemical mutants may, under favourable conditions, exchange growth substances through the medium, allowing a mixed culture to proliferate where the separate cultures would not (Lederberg, 1946). This test has been applied to a number of $E$. coli mutants deficient in sulphur metabolism (Lampen et al., 1947), but it is evidently not applicable to all Penicillium mutants (Bonner, $1946 b$; 1947).

\section{(i) Nutritional Mutants}

There is no specific selective technique whereby nutritional mutants can be obtained. Separate clones have to be established from single treated cells, and tested individually for the ability to grow on a minimal synthetic medium, i.e. one lacking added growth factors. Those clones for which this test reveals a synthetic deficiency are classified as mutants and characterised according to the nature of their biochemical deficiencies.

A technique to make the previous method somewhat easier has been developed. Instead of transferring single colonies representing single treated cells into separate culture tubes, an appropriate number of treated cells is plated directly into minimal agar medium. Cells of the wild nutritional type (prototropha) will form typical large colonies ; mutants will be able to proliferate little or not at all. The mutants are detected and recovered by the subsequent addition of growth factor supplements (in the form of yeast extract) to the plates. The nutrilites diffuse to the mutants and provoke their proliferation, thus allowing their identification at a suitable time by virtue of the smaller size of the mutant colonies as compared with the unhandicapped prototrophs (Lederberg and Tatum, 1946a).

Another technique has been developed with nearly as good results. The mixture of prototrophs and mutants is plated into a partially 
deficient medium, in which growth of mutants but not of prototrophs will be restricted. The mutants are again distinguished by their colony size. The main difficulty is to construct a medium which will contain just suitable concentrations of all the growth substances for which deficiency mutants are anticipated.

The assumption that the relative amounts of growth factors required (by mutants which cannot synthesise them) will be in the same ratios as the amounts of these factors present in prototrophic cells grown in minimal medium permits of a rational approach to this problem. A hydrolysate of bacterial cells was titrated on an existing biochemical mutant of $E$. coli to determine the optimum level at which it should be used; this level was then tested on other existing mutants, and on an X-rayed population for the detection of new mutants, with satisfactory results. This technique is particularly useful for the analysis of selection in mixed populations.

Additional mutations can be induced, and complex stocks carrying a number of biochemical markers developed (Lederberg and Tatum, 1946a; 1946b). Although mutations leading to biochemical deficiencies may not be detected without some difficulty, and are not to be recommended for quantitative mutational analysis, the mutants once obtained are useful for several purposes. The destruction by mutation of isolated biochemical functions is a precise analytical tool for biochemical studies. The mutants are in many cases suitable as bio-assay organisms for vitamins or amino acids (Ryan, 1946a). Moreover, new vitamin-like compounds may be discovered, and the functions of known vitamins may be studied.

For purely genetical purposes, biochemical mutants are valuable for recombination studies in bacteria and other organisms, as will be seen later. The inability of mutants to grow in minimal medium allows the quantitative detection of reverse-mutations even though they occur in only a few cells among a large population. A great many mutants, some recurrent, are available for this type of study. The development of multiple mutant stocks, either by recombination or repeated mutation, permits of the comparison of several loci under an identical treatment, or their covariance analysis in tests of spontaneous mutation (Tatum, 1945). Nutritional adaptation based on reverse-mutation has been observed and studied genetically at several loci in Neurospora (Giles and Lederberg, I948; Ryan and Lederberg, 1946) and Ophiostoma (Fries, 1946).

\section{(ii) Fermentative Mutants}

These are a class of biochemical changes similar to nutritional mutations, except that it is the breaking down of sugars or other carbon sources that is affected rather than the building up of growth factors. In bacteria they are easily detected as variations in the production of acid from a given substrate. Indicator media, such as eosin-methylene blue agar, are available which respond to the 
production of acid by colour changes in the substrate or in the colony itself.

The classical example of a bacterial mutation, the acquisition by so called E. coli mutabile of the ability to ferment lactose, is a progressive modification which can be selected for by the use of differential media selectively favouring lactose-positive mutants. Mutations to the loss of the ability to ferment lactose or other sugars on the other hand, may be detected by plating treated bacteria on an indicator medium, and looking for non-fermenting colonies. Other enzyme changes should be detectable with equal facility if appropriate indicator media can be devised.

In most instances of selection for specific mutants, as in the reversion of nutritional mutants, or mutations for resistance to bacteriophage, conditions are designed to afford a maximal selective differential between the major and the mutant component of the population. By this procedure, the number of mutants only, not of mutations, is counted. Sometimes it may be advantageous to apply only a partial differential so as to allow a direct estimate of mutations occurring during growth. For example, if a culture of a lactosenegative mutant is inoculated on an indicator agar containing peptone and lactose, the parent lactose-negative cells will proliferate and form colonies at the expense of the peptone only. A number of button-like projections then appear. These are found to consist of cells which have reverted to the lactose-positive condition. The ability of such cells to utilise the lactose in their nutrition apparently confers a partial selective advantage over them so that they can project out of the more restricted lactose-negative growth.

The sporadic distribution of such papillæ strongly suggests that each one is the result of a distinct mutation. It may appear that difficulties in the quantitative development of this type of analysis would make it inferior to one based on the enumeration of mutant cells in a population in liquid culture, but it must be recalled that purely mathematical difficulties still remain in calculating the spontaneous mutation rate from the mutant frequencies. Furthermore, the determination in liquid culture is unusually sensitive to slight, perhaps unsuspected selective differentials in the growth medium.

It is in the problem of the genetics of mutability, however, that analysis based on counts of papillæ may be most useful. The detection even of infrequent gross changes from cell to cell in the spontaneous but genetically determined mutation rate would be technically unfeasible by any other method. Yet it has been a simple matter to select from a lactose-negative population variant types which differ only in their rate of reversion to lactose-positive (L., unpub.).

Papillæ are not confined to colonies of fermentation mutants but can be expected wherever a partial differential is imposed within a colony between the main type and mutants derived from it. The 
basis of these differentials may be either a relative nutritional deficiency as in the case just cited, or a relative resistance to growth-inhibitory substances incorporated in the medium, such as sodium chloroacetate (Penfold, 1913) or lithium chloride (Kelner, 1947).

\section{(iii) Phage Resistance}

Mutations of bacteria for resistance to bacterial viruses or bacteriophages to which they were previously sensitive have recently been the object of extensive study (Demerec and Fano, 1945; Luria, I946 ; Luria and Delbrück, 1943). In contrast to the quantitative responses commonly found in drug resistance, virus resistance is usually an all-or-none affair, conditioned by the failure of phageresistant mutants to adsorb the phage (Delbrück, I946a; Henry and Henry, 1946).

In a series of bacterial mutants resistant to each of a series of phages the mutational resistance has been found to show a variable degree of specificity. Curiously, the patterns of cross-resistance, i.e. the set of phages to which a given phage-resistant mutant may be resistant, do not always bear an obvious relationship to the morphological or serological classification of the phages themselves (Delbrück, 1946a). Furthermore, resistance to a given phage may apparently be accomplished by any of a number of genetic changes, as shown either by the cross-resistance patterns of the mutant types (Demerec and Fano, 1945) or by recovering sensitive recombinants from the genetically distinct resistant types (Lederberg, 1947b).

The mutational pattern of $E$. coli $B$ to resistance to a series of viruses labelled $T_{I}$ to $T_{7}$ has been studied by Demerec and Fano (1945) and Luria (1946). They have determined the spontaneous rates of mutation to a number of primary resistance patterns, for example, ( $\left.\mathrm{T}_{1}, \mathrm{~T}_{5}\right),\left(\mathrm{T}_{\mathrm{I}}\right),(\mathrm{T} 6),\left(\mathrm{T}_{3}, \mathrm{~T}_{4}\right),\left(\mathrm{T}_{3}, \mathrm{~T}_{4}, \mathrm{~T}_{7}\right)$, where the figures in a single bracket refer to the phages, resistance to which is apparently acquired at the same time. The spontaneous mutation rates to these primary resistant types vary from $\mathrm{ca}$. $\mathrm{IO}^{-7}$ to $\mathrm{IO}^{-9}$ per cell per generation. In addition, certain more complex types are found more rarely, ca. $10^{-10}$ per cell per generation. These complex types simulate the superposition of the phenotypes of two primary types. Their origin from the coincidence of independently occurring primary mutations is unlikely because of their relatively high frequency, although Luria has suggested (1946) that their " simultaneous occurrence might be brought about by some type of mass rearrangement of the genetic material of the bacterial cells, possibly comparable to that responsible for chromosomal rearrangements in higher organisms." Unfortunately, recombination tests in $E$. coli $B$ have not been successful, and the mutation-pattern analysis in $E$. coli $K-12$ has not yet been advanced to the point of a genetic test of this hypothesis. One would also expect to find that complex 
types would show a non-linear increase with irradiation if they were the result of chromosome rearrangements.

On the other hand, clear-cut proof of independence of mutations has never been obtained. There may also occur in bacterial populations sub-clones whose total spontaneous mutability is much greater than average. Such a situation would also lead to an apparent excess of coincidences. These should be revealed in several ways, for example, by a localised or sectorial distribution of reverted papillæ in lactose-negative colonies, or by correlations between the number of reverse-mutants at each of the two mutant loci of a double biochemical mutant in a series of replicate cultures. Neither of these situations has been found to occur (Ryan, I946b).

An additional complexity has been introduced by Luria's discovery of genic interactions in $E$. coli $B$, resistance to $T_{2}$ apparently being hypostatic to the wild-type alternative to the resistance pattern $\left(\mathrm{T}_{3}, \mathrm{~T}_{4}, \mathrm{~T}_{7}\right)(\mathrm{I} 947 a)$. $\mathrm{T}_{2}$-resistance can therefore only be manifested

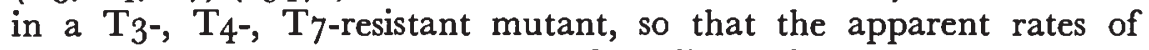
mutation to $\mathrm{T}_{2}$-resistance are widely different in the wild type and in the $\mathrm{T}_{3-}, \mathrm{T}_{4-}, \mathrm{T}_{7-\text {-resistant types. }}$

A factor which may be of importance, both theoretically and technically, is the occurrence of virus mutants which attack bacteria resistant to the ancestral phage. In most instances the rate of phage mutation is quite low, but it does contribute an element of biological variability to the reagents which may sometimes lead to complicated results. Bacteria can also mutate in turn to resistance to mutant phage. To what extent this process of complementary bacteriumphage mutations may go is not known, but its genetic analysis might well help to show the nature of the mutated specificities.

\section{(iv) Drug Resistance}

Another category of mutant which can be readily selected for are those affecting resistance to anti-bacterial chemicals or "drugs." No agent has yet been described to which relative increases in resistance have not been found to occur. Wherever thoroughly analysed (Luria, $1947 b)$, this type of adaptation seems to be the result of selection of spontaneous mutants. In most cases drug resistance shows a high order of specificity. Mutations affecting resistance to penicillin, streptomycin, and sulfonamides, for example, are independent of one another. On the other hand, mutational resistance is often a quantitative affair and seems to be controlled by a polygenic system which makes it rather difficult to distinguish different genotypes ( $c f$. Demerec, I945; Oakberg and Luria, I947).

Certain complications arise in this field, including variability in potency of various drugs with changes in the medium, inoculum size, or other factors which are difficult to control. Some resistant mutants are unstable and may revert to the sensitive state. The reversion 
may be accelerated by selective differentials inimical to the mutant on ordinary media (Witkin, I947a). These differentials may assume a bizarre aspect. For example, the resistant mutant may require the drug for growth, as described for several bacteria with streptomycin (Miller and Bohnhoff, I947; Paine and Finland, 1948), and for Neurospora with sulfonamides (Emerson, 1947). Such requirements may be based on either the incorporation of streptomycin or sulfonamide into the microbial protoplasm, or more likely, on the adaptation of the organism to the presence of the inhibitor to the point where the enzymatic structure is out of balance in its absence.

In certain cases, drug-resistance may be controlled in qualitative fashion by a single factor, but nevertheless be associated with biochemical deficiencies. For example, Penfold (I9I3) reported that cultivation of $E$. coli on nutrient agar containing sodium chloroacetate induced the formation of papillæ resistant to this agent. Cultures isolated from the papillæ proved to be unable to form gas from sugars. A reinvestigation has led the present author to the conclusion that the chloroacetate simply selects spontaneous resistant mutants which are blocked in the dissimilation of pyruvate. The relative inability of the mutant to assimilate acetate provides an opportunity (of which there are far too few) of specifically selecting for allelic states of a gene, as well as for a biochemical study of acetate metabolism. The specific connection between chloroacetate-resistance and the biochemical deficiencies remains enigmatic.

There are at least three other examples supporting the possible efficacy of this type of approach. Stier and Castor (I94I) have made a fragmentary report of the development of cyanide-resistant mutants of yeast lacking cytochrome oxidase. Wiggert and Werkman (1939) have recorded that suspensions of Propionibacterium, grown in the presence of fluoride, dissimilated glucose via a non-phosphorylative pathway. It cannot be assured that a genetic change is responsible since the organisms were not subsequently propagated in the absence of fluoride. More recently, however, Clapper (I947) reported that the ability of Lactobacillus cultures to dissimilate glucose was permanently impaired by cultivation in fluoride. Finally, it was found by Kohn and Harris (I942) and confirmed by Tatum (I946) that cultivation of $E$. coli in sulfonamide media led to the production of sulfonamide-resistant strains which required methionine, the biosynthesis of which is known to be affected by sulfonamides.

In these cases, a simple relationship between the biochemical site of inhibition by a drug and the biochemical deficiencies of resistant mutants is obvious, but it is still a mystery that the deficient organisms should be resistant. Continued genetic and biochemical analysis along these lines should lead to the elucidation of the nature of drug resistance generally, and also provide useful specific modifications of metabolic pathways for biochemical studies. 


\section{(v) Antigenic Variation}

The mutant characters just summarised are the most suitable for genetic analysis for technical reasons, but most of the work on bacterial variation has been done on the complex of morphological and antigenic characters concerned with virulence and lumped under the name " dissociation." A genetic treatment of these phenomena would in present stages of information have to be quite superficial, and perhaps be confined to the generalisation that mutation and selection can account for most of it. A lucid discussion of this field is provided by Dubos (1945) and by Harrison (1947).

There is one group, however, Salmonella, which has been rather thoroughly analysed serologically so that the antigenic constitution of a culture can be to a large measure described as the sum of qualitative units. These units are the serological atoms distinguishing between strains ; they are also the units of mutation. The success of antigenic analysis in this group is largely due to the occurrence of different combinations of antigens in different strains, so that antisera against one complex can be decomposed or purified by absorption with other cells containing some components in common. When antiserum against one strain is absorbed with cells having all but one component in common, antibodies to this component are the only ones left in the supernatant serum. A highly specific reagent is thus provided.

The apparently random concurrence of different antigens in different strains led Bruce White (1926) to the conclusion that the group had evolved through loss mutation of some of the components of a highly complex ancestor. Genetic recombination is perhaps a more obvious a priori interpretation, but there is as yet no evidence of it in Salmonella.

Loss mutations of somatic antigens have been described by numerous authors ( $c f$. " Formwechsel" in Kauffmann, I94I), but another mode of variation affecting the flagellar or $\mathrm{H}$-antigens is perhaps of greater interest, namely phase variation. It was found by Andrewes (1922) that apparently pure cultures of Salmonella contained cells which were different in their flagellar antigens. Two types were generally observed and were called phases. A culture isolated from either phase may remain fairly constant, but one phase can change to the other. In some instances the rate of variation is so small as to require the use of specific antiserum against one phase to facilitate the isolation of the other. The components of one of the phases are prevalent in many other strains so that this is called the non-specific phase, while the specific phase generally consists of less widely distributed antigens. The distinction is arbitrary, however, and the designation phase $\mathrm{I}$ and phase 2 respectively is preferable.

The remarkable feature of phase variation, when one attempts to analyse it on a mutational basis, is that it seems to consist of a mutational shift from one complex of characters to another. From 
strain to strain there is no consistent correspondence between the components of phase I and phase 2 ; in certain cases one of the components may be common to both phases. Finally, variants have been described in which one component of one phase has been lost or altered with no corresponding modification of the alternative phase. These considerations do not support the conception that phase variation is due to the mutation of a simple modifier gene. The Salmonella group appears to contain a double set of genetically controlled specificities, one or the other of which dominates at any time. In certain species there are more than two phases (Bruner and Edwards, I94I). Most Salmonella workers have suggested that antiserum induces phase variation, but without excluding the likely possibility of selection of spontaneous variants.*

\section{GENE RECOMBINATION IN BACTERIA AND BACTERIOPHAGE}

Gene recombination has been discovered in a strain of Escherichia coli, permitting for the first time of a mendelian or combinatorial analysis of bacterial mutations (Lederberg, 19476 ; Lederberg and Tatum, I946a; I946b; Tatum and Lederberg, 1947). Gene recombination was inferred from the presence in mixed populations of multiple biochemical mutants of types characterisable as recombinations of the genotypes of the "parents." The recombinants were detected in the same way as reverse-mutations: they are prototrophs capable of growing in minimal medium, which the mutant parents are not. By using multiple mutants, however, "contamination" with leverse-mutants was avoided, and prototrophs appeared only in mixed populations. Other character differences were introduced into the parents, and these were found to reappear in all possible combinations in the prototrophs, although with varying frequencies. From the discovery of these types the existence of a zygote was inferred. Genetic interaction via the medium in the form of parcels of the transforming factors, which we shall consider later, is an alternative possibility rendered unlikely, however, by the evidence.

The evidence suggests that this bacterium has a life-cycle comparable to Zygosaccharomyces: the vegetative cells are haploid (but not necessarily uninucleate); fertilisation is homothallic or unrestricted genetically; the putative zygote undergoes immediate reduction without any intervening mitosis. The number of gametophytes issuing from a single zygote is not definitely known. All the mutant characters so far studied have segregated and combined in

* Dr R. F. Kimball has pointed out to the author that a comparable situation exists in Paramecium aurelia (Jennings, 1941). Clones of a given mating type may "self-differentiate" to an alternative type. This shift is reversible. As in Salmonella, the two alternative types which may be exhibited are fixed for a given clone and are not constant for all clones of a particular initial type. Genetic analysis of cross-bred types has not yet elucidated the mechanisms. Hcwever, Sonnebom's observations on antigenic variations in Paramecium, discussed above, may prove to give us the answer. 
an orderly fashion but show interactions in their segregation which have been interpreted in terms of linkage.

The linkage hypothesis was tested in a few instances by studying the effect on the proportions of prototrophs carrying a given alternative of alternating the parent with which it was introduced. This is a criterion for mendelism ; in Fisher's words (1947): "The gametic frequencies are invariant in respect of any gene substitution applied systematically to the genic content of an organism and of the gametes it produces." In this case the haploid vegetative progeny correspond to the gametes.

Within the limits of the variation found in replicate experiments, the segregation ratios showed a good fit in terms of the linkage view, so that non-independent segregations must be based on the machinery of segregation and crossing-over. Some 20 markers have been shown to belong to a single linkage group ; about eight have been located fairly definitely and some evidence of their linear arrangement obtained. The recombination process is too rare $\left(c a . \mathrm{IO}^{-6}\right.$ cells yield prototrophs) to encourage a search for the zygote or its cytological characterisation. Whether recombination is peculiar to $E$. coli $K-12$ cannot yet be told since only two other strains have been examined, and these were entirely fruitless. The process is so rare as to require specific selective techniques for its detection, but the selection need not be, as we shall see, on a nutritional basis.

\section{(i) Materials for Recombination Study}

New and helpful techniques have been developed as we have seen, but the development of multiple nutritional mutant stocks is still too laborious to be feasible for the routine screening of other organisms for the occurrence of recombination. Moreover, there are bacteria, such as the Staphylococci, whose nutrition is already so complex that it is difficult to envisage much more nutritional degradation. Since only a single bacterial strain has proved successful so far, the reader might well demand whether there are other techniques applicable to this purpose which require a smaller investment in time and labour.

The principle of selection for specific recombinational genotypes is, at least in theory, not confined to mutant types produced in the laboratory. For one thing, there occur many closely related bacteria which have divers nutritional requirements, $a b$ initio, and should be suitable for recombination tests (Dunn et al., 1947; Lederberg, 1947a). A cursory application of this principle to certain Salmonelia types (L., unpub.) was unsuccessful, however, largely owing to reverse mutation of nutritional requirements.

Phage resistance might be an admirable character for the detection of recombinants were it not for the occurrence of complex resistance types by frequent mutation. Luria $(\mathrm{r} 947 b)$ has unsuccessfully tried 
this method on $E$. coli $B$, a strain with which, however, nutritional experiments gave the same negative result (Tatum and Lederberg, 1947).

Mutations for resistance to antibacterial agents are perhaps the easiest to obtain and produce in sequence. They should therefore find considerable application in surveying the bacterial kingdom for sexual reproduction. With so many drugs it should be easy to develop multiple mutant stocks. In addition, stocks may be used which are resistant to a high level of single agents as a result of mutations in sequence of several genes without danger of confusion arising from the development of high-level resistance in a single mutational step (Demerec, 1945).

Resistance to drugs might also provide genetic markers for viruses (Fitzgerald and Babbitt, 1946; Jones and Schatz, 1946) and even for the malarial plasmodium (Williamson et al., 1947), in which it has been very difficult to obtain suitable character alternatives for genetic study.

Mutations upon which a selective differential cannot be experimentally imposed are not without value, in spite of their inutility for the initial detection of recombinants. Such variations as those involving sugar fermentations, pigment, and colonial morphology belong in this category. Where a hypothetical hybrid form is readily isolated, e.g. "stars" in Phytomonas (Braun and Elrod, 1946), "large bodies" in Proteus (Dienes, I946 ; 1947) selectible characters may be superfluous, and the primary consideration becomes the ease of obtaining and scoring them.

\section{(ii) Bacteriophage}

Another primitive micro-organism for which evidence of genetic recombination has been obtained is bacteriophage. Using phages $\mathrm{T}_{2}, \mathrm{~T}_{4}$, and T6, Hershey (1946) has found, among the lytic products of a mixedly infected cell of $E$. coli, phage particles of new genetic types. These may be described as recombinations of the characters of the infecting particles. Using a statistical rather than direct control of the parental genotypes, Luria (I947c) found that in ultra-violet treated suspensions of phage there are particles which are, individually, incapable of carrying out lysis of a bacterium. When two or more inactivated phage particles are adsorbed on a cell, however, lysis may occur and liberate normal phage. This was interpreted as an exchange among the wild type alleles of ultra-violet-induced lethal mutant genes. There is some evidence of linkage or other resistance to interchange in Hershey's material which is not found in Luria's.

\section{TRANSFORMATIONS}

Bacteria are unique in providing a number of examples of specifically directed mutations or transformations. The most familiar 
illustration, no doubt, is the type transformation of pneumococci, recently reviewed by McCarty (1946). The type specificity of pneumococci is determined by the presence of chemically distinct polysaccharides in the capsule of the cells. Colonies of the specific types are " smooth," as compared with those of a non-specific " rough" type, the cells of which lack a capsule.

Griffith (1928) first observed that heat-killed suspensions of smooth pneumococci would, in the body of an inoculated animal, convert rough cells to smooth of the same type as that of the heat killed suspension. Other investigators succeeded in performing these changes in vitro. This work culminated in the partial purification of the transforming principle (Avery et al., 1944) and its characterisation as a polymerised desoxyribonucleic acid. The total absence of all other components is not readily established, although none can be detected with available methods. The criticism of Mirsky and Pollister (1946) should be noted, however. The further chemical characterisation of the transforming principle is one of the most urgent problems of present-day biology, since it behaves like a gene which can be transferred by way of the medium from one cell to another.

An analogous transformation system has been described in certain strains of Escherichia coli (Boivin, 1947). Here, too, a desoxyribonucleic acid is involved, but the active principle has not yet been characterised with the same thoroughness as the pneumococcus principles. As in the pneumococci, the directed mutation is exclusively one-way (from

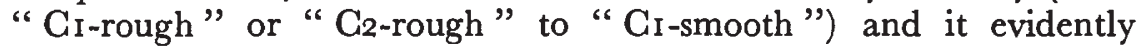
involves the acquisition of an antigen by a strain lacking it. An initial statement that a loss of invertase accompanied the new antigenic acquisition was retracted.

Weil and Binder (1947) have more recently reported transformations of Shigella from one antigenic type to another by the use of extracts prepared according to Boivin's directions. They have indicated, however, that the experiments are not yet sufficiently reproducible to permit of the purification and characterisation of the active agent.

Other reports of directed mutations appear in the bacteriological literature; the investigations were in no case motivated by the now very evident genetic implications, and their validity is perhaps questionable. The pertinence of transformations to modern genetic problems is so great as to justify a somewhat detailed consideration of these reports in the hope that this may stimulate a re-examination of some of them.

The acquisition of virulence by an avirulent culture, following cultivation in sterile filtrates of a virulent strain has been reported in several cases : Pseudomonas pyocyaneus (Legroux and Genevray, I933), a horse-pathogenic coliform (Van Saceghem, 1935), Salmonella typhimurium (Mackenzie and Brewster, 1947), and the yeast-like 
Mycotorula (Candida) albicans (Negroni, 1936). This type of change does not lend itself to genetic analysis, but the first of these reports, at least, is rather convincing.

Ciantini (1944) has published the rather remarkable observation that bacteria of the genus Klebsiella (Friedländer's bacillus) acquired the serological specificity of pneumococci types from which inducing extracts had been obtained.

A multitude of papers deal with what is called " paragglutination." As originally defined the term referred to the isolation of strains biochemically resembling Escherichia coli but agglutinating to high titres in antisera for enteric pathogens-Shigella and Salmonella. It is now known that many enteric Gram-negative bacteria may have antigens in common, particularly in their rougher phases, which adequately accounts for or describes paragglutination. Kuhn and Ebeling (1916), however, initially postulated that typical $E$. coli paragglutinated owing to its absorption of antigenic receptors (or transforming principles) produced by the pathogenic flora with which it was intimately mixed in the intestine of an infected patient. The hypothesis provoked many attempts to induce paragglutination experimentally and led, for example, to Griffith's much more convincing demonstration.

The more recent studies of Weil and especially of Boivin have amply realised the possibilities that were suggested by the earlier investigators, so that a mere citation of the earlier references, which have been largely overlooked, should be sufficient (Busson, I9I I ; Oda, I920 ; Salus, I917 ; Wollman and Wollman, I925).

Among the Streptococci, there is a similar plethora of descriptions of transforming systems. Cantacuzene and Bonciu (1926) found that Streptococci which did not ordinarily agglutinate in the sera of scarletfever convalescents became agglutinable after treatment with filtrates of pharyngeal exudates or urines of patients. They ascribed this modification to a filterable virus, on the analogy of present-day interpretations of transformation. Filtrates of cultures of scarlatinogenic Streptococci were also effective.

These findings have been confirmed by some investigators (Giorgetti, I943 ; Martin and LaFaille, I926 ; Sacquepée et al., 1929) but not by others (Prochazka, I930; Schwenkenbecher, I940; Zoeller and Meersseman, 1927). Frobisher and Brown (1927) have also reported the transmission from active to inactive strains by way of sterile filtrates of the capacity to produce the erythrogenic toxin. The heritability of the acquired character was limited, but toxin was actually produced by the changed strains.

The report by Burnet (1925) on the acquisition of "paramelitensis" antigens by Brucella melitensis grown in filtrates of the former has been widely cited. Current opinion (Pandit and Wilson, 1932) that paramelitensis and melitensis are simply rough and smooth phases of the same organism, capable of spontaneous change one into the 
other, does not, however, support Burnet's conception of a specific transforming virus.

Another transformation has been reported whose interpretation, if the facts are confirmed, will have to be more complex than that of gene transfer. Cultivation of Eberthella (Salmonella) typhosa or of $S$. paratyphi $A$ on agar containing ro per cent. horse serum resulted in strains containing the Forssman heterophile antigen which is present in the horse serum. The acquired property was heritable for at least 2 I mass transfers, and control cultures maintained on beef extract agar did not develop the antigen (Holtman, I939; $c f$. Veblen, I929). It is impossible to assay the possible role of selection of spontaneous mutants in this procedure; a priori it would seem to be remote. The unique quality here is that transformation was accomplished with material, neither of bacterial origin nor containing polymerised nucleic acid, such as are so characteristic of verified instances of directed mutations.

\section{EVOLUTION AND MICROBIAL POPULATIONS}

With their reduced biological time-scale it is not difficult to discover evolution in progress in micro-organisms. Population genetics of pathogens has long gone under the name of epidemiology. Until recently, it was confined to the distribution of these microbes primarily in relation to virulence, a complex so intricate in the interplay of host and parasite relationships that its analysis seems nearly hopeless. The development of chemotherapeutic agents in the past decade, however, has directed emphasis toward the distribution of the somewhat simpler factors determining drug resistance. It has been pointed out that mutations of bacteria to drug resistance are the most critical factors in limiting the application of these agents, and that medical science may look forward to a never-ending cycle of new drugs and mutant bacteria.

In a similar fashion, the Darwinian processes of spontaneous variation and natural selection account for continuous development of new biotypes of phytopathogenic fungi which attack varieties of plants developed to resist the preceding flora. We are equally able to predict the development of new microbial types capable of initiating pandemic disease such as rgr 8 influenza (Burnet, r945). Concrete information on mechanisms of microbial evolution is, however, conspicuous by its absence. The following sections must therefore be speculative.

\section{(i) Physiological Evolution}

Lwoff (r943) has maintained that a major element of evolutionary change consists of the mutational loss of biochemical functions. He has collected a mass of data showing that in various groups (chiefly amongst the Protista) specialisation, particularly in the direction of 
parasitism, is accompanied by the dropping out of biochemical capacities.

Many organisms are characterised by the inability to manufacture various growth factors. In the Salmonella these requirements are no doubt due to regressive losses from a more autotrophic ancestor. The evidence is first, that there is great diversity of nutritional requirements with little overlapping except for tryptophane. The common denominator and the most frequent type is free of growth requirements. Secondly, many of the requirements can be readily extinguished by a process apparently comparable with the reversemutation of artificial biochemical mutants. It seems improbable that a synthetic process could be so readily evolved de novo, as would be required if this were not reverse-mutation (Lederberg, 1947a).

To describe deficient types as part of a process of specialisation is easier than to account for their persistence in terms of natural selection. Beadle (1945a) has explained "regressive orthogenesis" as the result of mutation pressure. On the simplified assumption that the presence of a growth factor in the environment neutralised the selective advantage of a physiologically active gene, the loss of that gene solely as a result of mutation pressure would be predicted. Beadle (1945a) and Ryan (1946b) have also suggested that, once a gene controlling a terminal stage of synthesis has been lost, additional chance mutations blocking other steps in the synthesis would accumulate. As a result, " all steps in a given synthesis will tend to be lost eventually" (Beadle, I945a). This revival of the doctrine of the loss of functions through disuse places considerable emphasis on the direction of evolution by mutation, and assumes that these mutations will be neutral in natural selection. It seems to the writer that no physiological mutation can be so innocuous that its selection coefficient would be of the same low magnitude as characterises mutation pressure.

\section{(ii) Population Studies}

At first sight, it might appear that there should be a simple predictable basic of selective relationships between a "wild-type" and a mutated gene. In environments in any way deficient in the growth factor involved, the active allele should be preferred. In adequate milieux there should be either no preference, or, as has been suggested by Roepke et al. (1944), an economic advantage to the mutant. The advantage would result from the absence of the enzyme, the synthesis of which might have competed with other reactions for energy and for material. No very convincing demonstration of an economic differential has yet been made although, as we shall see, other types of mutant preferences have been found. In fact we do not know whether so-called inactivated genes are not still producing "enzymes" which have been modified to the point of loss or unrecognisability. 
It has been found experimentally that the population genetics of prototrophic and mutant alleles is more complicated than had been assumed. Ryan and Lederberg (1946) found that in heterokaryons of Neurospora, leucineless nuclei were selectively favoured over nuclei carrying the wild-type alternative. This selection occurred even on deficient media, so that its result was a population no longer able to grow at all on the medium on which selection had taken place. This phenomenon showed that the unit changes in an evolving system are local and have no necessary relationship to the survival value of the population produced. The biochemical mechanism of the selection process is not well understood, but other similar observations have been recorded in bacteria where it may be more readily elucidated than in systems operating through the mutant cytoplasm of a fungus (Ryan, unpub.).

Experiments with heterokaryons of wild type Neurospora and biochemical mutants other than leucineless (L., unpub.) suggest that it is difficult or impossible to purify a well-established heterokaryon by mass selections on a minimal liquid medium. The mycelium remains "parasitised" by the mutant nuclei which"derive their growth factor from the wild type. Heterokaryotic vigour due to unsuspected genetic diversities in the stocks may play a part in this affair.

Bacterial combinations have proved to be much more responsive to selection (L., unpub.), but mutants can be carried along in small numbers in mass transfers. This experience is, of course, comparable to the difficulties experienced by the early microbiologists in obtaining pure cultures of Azotobacter, etc.

Most of the reported studies on bacterial populations have involved rates of mutation which played a large part in determining the composition of the population (Bunting, I946 ; Shapiro, 1946), so that it has been difficult to assess the role of selection. Witkin (1947a) has shown that mixed cultures of wild-type $(+)$ and radiationresistant $(r) E$. coli $B$ contained a constant proportion of $+: r$ provided that transfers were made at least every 48 hours. Mixtures allowed to age over longer periods rapidly lost the $r$ component, so that at 20 days it had dropped from $8 \times 10^{-1}$ to $5 \times 10^{-7}$. Leise (unpub.) has found that the introduction of a few $S$ (avirulent) cells of the anthrax bacillus into large aged populations of $R$ (virulent) cells resulted within 2-3 days in the virtually complete replacement of the $R$ population by the $S$. Since spontaneous mutations of $R$ to $S$ were found, and the selective process was accelerated by cultivation at $42^{\circ} \mathrm{C}$., the explanation by mutation and selection of Pasteur's famous experiment of the attenuation of virulence of the anthrax bacillus by cultivation at high temperatures is justified.

Braun (1947) has studied the development of rough and smooth types in populations of Brucella abortus under a variety of conditions, but his experiments were not so designed that one can assess the relative importance of the growth rates of the $R$ and $S$ 
types, their possible interaction in mixed culture, and of the role of mutation in determining the composition of his populations. One can conclude from his experiments, however, that selection plays a predominant role in the "dissociation" of bacterial cultures, and that the selective values of different types are determined conjointly by the genotypes and the milieu.

A theoretical discussion of heterokaryotic populations has been elaborated by Beadle and Coonradt (1944) and by Pontecorvo (1946) on the basis of relative gene efficiencies. They conclude that, where growth factor requirements are the only selective factor, combinations of mutants of which the wild type alleles have a high efficiency will yield variable populations, whereas combinations of mutants with relatively inefficient wild type alleles will be stabilised at the optimum proportions. Experimental evidence bearing on this point is, however, limited.

Studies in the evolutionary genetics of micro-organisms also allow opportunity for " field work" for the examination of related organisms isolated from their natural habitats. We are, of course, limited in bacteria by the absence of any " natural" classification (Van Niel, 1946), but the confusion of bacterial taxonomy is greater in the higher taxonomic units than in the lower. We are left with groups such as the colon-typhoid-dysentery organisms, the pneumococci and the streptococci, of whose internal relationships there is no doubt. The geneticist cannot help, for example, but be struck by the cleavage of the colon-typhoid-dysentery group into lactose-positive and lactosenegative organisms, a cleavage which provides an excellent although of course not infallible diagnosis for pathogenicity or non-pathogenicity respectively. Since mutations converting a typical $E$. coli into a lactose-negative variant have been found (Lederberg, 1947b), one is inclined to wonder what the genetic or evolutionary reasons are for this cleavage. We have no reason to believe that Escherichia is any more or less exposed to lactose than a Salmonella which has essentially the same habitat. There are many similar unanswered problems, which are the more sharply delineated because we have the right to assume that within a group similar biochemical peculiarities are genetically homologous and probably related by direct descent.

The postulate that several steps in a single biochemical sequence may be dropped out one after the other has been used to explain the relative stability to reversion of some growth factor requirements. Lwoff (I943) has offered a possible illustration of organisms unable to synthesise either the pyrimidine or the thiazole components of thiamin, but the subsequent discovery of a single genetic change in Neurospora leading to the same effect disqualifies it (Tatum and Bell, 1946). Several organisms are known which require the pantoate moiety or the $\beta$-alanine moiety, or are unable to couple these to form the vitamin pantothenic acid (Ryan et al., 1945), but in no organism has it been shown that more than one of these steps is blocked. 
We are still too much in the dark about biosynthetic sequences to know how to look for many other examples. A mutational method for determining whether multiple blocks are the basis of an apparently irreversible requirement would consist of testing the strain not on a minimal medium but on the suspected precursors, and looking for functional reversions of the isolated segments of the biosynthetic sequence.

\section{(iii) On the Origin of "New" Genes}

The diversity of enzymatic functions in micro-organisms is far too great to allow of a single ancestral form from which present-day life has evolved exclusively by loss-mutations. There must be some way in which new specificities can be evolved and therefore " new" genes. As many geneticists have pointed out (cf. Metz, 1947), the duplication of already existing genetic material may play a prominent part. The fluid state of microbial evolution should make this group particularly satisfactory for the exploration of such mechanisms.

A genetic criterion for a duplicated gene is the occurrence of distinct loci each mediating the same biochemical process. In this state it might be manifested only as the stability of the biochemical step to loss by mutation. Such duplications could be detected if, in the evolution of different substrains, different members of the duplicated set have mutated, i.e. $a_{1}-a_{2}+$ and $a_{1}+a_{2}-$. Then the recessive type, $a_{1}-a_{2}-$, might be recovered by recombination of the two dominates. The occurrence of numerous morphological mutant phenotypes only in the first few generations of inbreeding of apparently wild type Neurospora (Lindegren, 1933) might represent such a phenomenon, but these spontaneous mutants have not yet been analysed. One may conclude on general grounds, however, that apparent identity of phenotype is no guarantee of isogenicity, since recessive alleles can be masked by duplication in just this way.

The method just described requires the unearthing of distinct strains between which there has already been such divergence as might interfere with hybridisation. There is another possibility, provided that at least one stock of the genotype $a_{1}+a_{2}-$ is available and the mutant $a_{1}-a_{2}-$ has been obtained. Phenotypic reversion of the $a$ character could result from the back-mutation either of $a_{1}$ or of $a_{2}$. If the latter reverts, the genotype $a_{1}-a_{2}+$ will have been obtained, which can be tested as above by crossing with the parental $a_{1}+a_{2}-$ and recovering the recessive type. Biochemical mutants of Neurospora (or of $E$. coli $K-12$ ) are well suited to this type of experiment, since reversions are readily selected for. In all test crosses, of course, one must use genetically pure material reisolated from the heterokaryotic mixture in which reverted nuclei will usually first be found.

The analysis of phenotypic reversion of several biochemical mutants in Neurospora (Giles and Lederberg, 1948 ; Ryan, 1946b; Ryan and Lederberg, 1946) and of lactose-negative mutants in $E$. coli 
(L.) has revealed genetic reverse mutation. But Houlahan and Mitchell (1947) have recently reported that the adaptation of a pyrimidineless strain of Neurospora involves the mutation of a suppressor of pyrimidineless rather than reversion of the original biochemical mutation. The genetic suppression was specific insofar as the suppressor gene did not affect biochemical genetic blocks of other steps in pyrimidine synthesis. It does not, therefore, involve the development of a new and independent route of synthesis but the taking over of the functions of the pyrimidineless gene as the result of mutation at another locus. Houlahan and Mitchell hesitate to describe the suppressor gene as a duplication of the pyrimidineless locus because of differences between the wild type and the suppressed mutant in response to inhibition by arginine. It is not known to what extent multiple alleles of a single locus might have a similar aspect, so that duplication cannot be ruled out entirely as the ultimate source of the reacquired genic specificity.

Duplication is a means by which an essential function can be preserved, while at the same time a source of new specificities is made available. When a vital function can be taken over by the environment, or more accurately, by the genes of other organisms in the ecological complex, duplication is no longer necessary to provide raw material for genetic differentiation. So called "latent genes" (Beijerinck, r912; Lederberg, r947a; Weir, 1947) which, although apparently inactive, are capable of reverting to a state of manifest activity may illustrate an intermediate phase in the shifting of a gene from one function in the synthesis of a nutrilite to an unknown alternative. On the other hand the selective advantages which are implied by the very occurrence of latent genes in field strains might be taken to indicate that the "latent gene" is already functioning in some manner beneficent to the organism, rather than that a selective advantage is associated with the mere inactivity of that locus.

Bona fide examples of mutations involving a qualitative change in gene function cannot be cited, because every apparent instance might simply represent a chemical consequence of the decreased or slightly modified activity of a gene-controlled enzyme. The apparent shift in function of a gene controlling the conversion of indole to tryptophane in $E$. coli $B$ to a phage-resistant phenotype (Anderson, 1946 ; Wollman, r947) illustrates this difficulty, because the possibility cannot be excluded that there is a direct chemical relationship between tryptophane metabolism and phage susceptibility.

The concept of a "shift" mutation becomes particularly important when one tries to formulate experiments on the evolution of new functions (van Niel, 1946). For example, if one selects for a mutative augmentation of the biosynthetic function of, say, a Salmonella, and secures it, what evidence could be brought to bear on the questionis this a novel function for the locus which has mutated, or is it a reversal of a previous mutation inactivating that locus? Since this 
is an historical question there can never be a decisive answer. But if the development of one enzymatic function is specifically associated with the loss of another, and the one which is lost can be regarded as primitive as with the synthesis of a nutrilite, or the dissimilation of an important intermediate, one would be entitled to say that a shift mutation had led to a new function for that locus.

In terms of such an economy of genes, one can supply an alternative explanation of Lwoff's " regressive orthogenesis" : genes once used for biosyntheses have been made available for other functions of greater selective value in the specialised environment.

As well as being raw material for new gene functions, the mutated gene also provides substrates which accumulate in quantity due to the interference with the normal reaction sequence. In Neurospora, such accumulated intermediates may be chemically unstable and polymerise to form pigments. The development of alternative pathways might result in more useful by-products, as has been suggested for the evolution of the synthesis of penicillin (Bonner, 1947).

\section{CONCLUSION}

The progress of microbial genetics has been so rapid that many of the statements in this review may be outmoded before it reaches print. In this haste, it is all the more important to re-examine the underlying problems.

Of these, the most important is to understand the material basis of an hereditary change. So far, it has been necessary to rely heavily on analogy with higher forms, but more and more independent evidence is being brought forth that alterations in unit particles, which may be called genes, are often responsible. As this evidence accumulates, studies on mutagenesis and especially on directed mutations or transformations can be placed in their proper relationship to our accumulated knowledge in classical genetics.

A scarcely less important direction of research is gene action. Physiological variation is much more readily studied in microbes than in higher plants and animals, especially as enzymatic mutants can be readily obtained. By a combination of serological, enzymological and genetic studies on bacteria and other microbes we may hope to augment our almost negligible understanding of gene specificity.

Finally, the rapidity of microbial reproduction, the magnitude of their populations, and the facility with which critical factors in their environment can be altered, make microbes, especially bacteria, incomparable material for experimental evolution. So far, the emphasis has been in the direction of degradation of functions, but the more important opportunity is perhaps in the analysis of the development of new gene forms, whose detection is feasible only by the use of selective procedures on immense populations.

This paper was written in part at the Osborn Botanical Laboratory, Yale University. Experiments carried out there were supported by a grant from the 
Jane Coffin Childs Memorial Fund for Medical Research, under the direction of Professor E. L. Tatum. The writer is indebted to Professor Tatum for his continued interest and encouragement.

The paper is published by permission of the Director of the Agricultural Experiment Station.

\section{REFERENCES}

ANDERSON, E. H. I946. Growth requirements of virus-resistant mutants of a bacterial strain. P.N.A.S. 32, 1 20-1 28.

ANDREWES, F. W. 1922. Studies in group agglutination. F. Path. Bact. 25, 51 5-52 I. AUERBACH, C., ROBSON, J. M., AND CARR, J. G. 1947. The chemical production of mutations. Science 105, 243-247.

AVERY, O. T., MACleOD, C. M., AND McCARTY, M. I944. Studies on the chemical nature of the substance inducing transformation of pneumococcal types. Induction of transformation by a desoxyribonucleic acid fraction isolated from pneumococcus Type III. F. exp. Med. 79, I 37-I 58.

BAUCH, R. I932. Über die genetischem Grundlagen von $\mathrm{Z}$ wittrigkeit und neutralem Verhalten bei Brandpilzen. Planta $17,612-640$.

BAUCH, R. 1941. Experimentelle Mutationsauslösung bei Hefe und anderen Pilze durch Behandlung mit Camphor, Acenaphthen und Colchicin. Naturwissenschaften 29, 503-504.

Beadle, G. W. I945a. Genetics and metabolism in Neurospora. Physiol. Rev. 25, $643-663$.

BEAdLe, G. W. I 945b. Biochemical genetics. Chem. Rev. 37, I5-96.

BEADLE, G. W. 1946. Genes and the chemistry of the organism. Amer. Sci. 34, $30-53,76$.

BEADLE, G. W., AND COONRADT, V. L. 1944. Heterocaryosis in Neurospora crassa. Genetics 29, 291 -308.

BEAdLe, G. W., AND TATUM, E. L. I945. Neurospora II. Methods of producing and detecting mutations concerned with nutritional requirements. Amer. F. Bot. $32,678-686$.

BeIJERINCK, M. W. I9I2. Mutationen bei Mikroben. Folia microbiol. Delft. I, 4-1 oo. BEVER, w. M. I940. Studies on hybridization and genetics in Ustilago hordei race 6 and $U$. nigra races $2 \mathrm{~A}$ and 4 . Dissertation, Univ. of Wisconsin.

Borvin, A. 1947. Directed mutation in colon bacilli, by an inducing principle of desoxyribonucleic nature : its meaning for the general biochemistry of heredity. Cold Spr. Harb., Symp. Quant. Biol. 12, 7-1 7 .

BoNNER, D. 1946a. Biochemical mutations in Neurospora. Cold Spr. Harb., Symp. Quant. Biol. 11, I4-24.

BonNer, D. 1946b. Production of biochemical mutations in Penicillium. Amer. F. Bot. 33, 788-791.

BONNER, D. I 946 c. Further studies of mutant strains of Neurospora requiring isoleucine and valine. 7. Biol. Chem. 166, 545-554.

BONNER, D. 1947. Studies on the biosynthesis of penicillin. Arch. Biochem. 13, I-9. BRAUN, A. C., AND ELROD, R. P. 1946. Stages in the life history of Phytomonas tumefaciens. F. Bact. 52, 695-702.

BRAUN, W. I947. Bacterial dissociation. Bact. Rev. II, 75-I I4.

BRUNER, D. W., AND EDWARDS, R. R. I94I. The demonstration of non-specific components in Salmonella paratyphi A by induced variation. F. Bact. 42, 467-478. BULler, A. G. R. I94I $a$. The diploid cell and the diploidisation process in plants and animals, with special reference to the higher fungi. I. Bot. Rev. 7, 335-387. BULleR, A. G. R. I 94 I $b$. II. Bot. Rev. 7, 389-43I.

BUNTING, M. I. 1946. The inheritance of color in bacteria with special reference to Serratia marcescens. Cold Spr. Harb., Symp. Quant. Biol. II, 25-32.

BURGEFF, H. I9I 5. Untersuchungen über Variabilität, Sexualität, und Erblichkeit bei Phycomyces nitens. Flora 107, 259-316. 
BURGefF, H. I928. Variabilität, Vererbung und Mutation bei Phycomyces blakeseleeanus Bgff. Z.I.A.V. 49, 26-94.

BURKHOLDER, P. R., AND GILES, N. H., JR. 1947. Induced biochemical mutations in Bacillus subtilis. Amer. F. Bot. $34,345-348$.

BURNET, E. 1925. Actions d'entraînement entre races et éspèces microbiennes. Arch. Inst. Pasteur Tunis 14, 384-403.

BURNET, F. M. I945. Virus as organism. Cambridge, Mass : Harv.

Busson, B. I9I I. Über Coli-Mitagglutination durch Immunsera verwandter Arten und deren theoretische und praktische Bedeutung. Zbl. Bakt. 57, 351-366.

BUZZATI-TRAVERSO, A. 1947. A bibliography of genetic research published in Italy and Germany, I939-1945. Heredity I, I9-5I.

CANTACUZÈnE, J., AND Boncru, o. I926. Modifications subies par des streptocoques d'origine non scarlatineuse au contact de produits scarlatineux filtrès. C.R . Acad. Sci. Paris 182, I 185 -I 187.

GAtcheside, D. G. 1944. Polarized segregation in an Ascomycete. Ann. Bot. 8, I I 9-I 30 .

Chen, T.-T. I940. A further study of polyploidy in Paramecium. Chromosomes and mating types in Paramecium bursaria. F. Hered. 30, 249-251.

christensen, J. J. I931. Studies on the genetics of Ustilago zea. Phytopath. Z. 4, I 29 -I 88 .

CHRistensen, J. J., AND RODENhiser, H. A. I940. Physiologic specialization and genetics of the smut fungi. Bot. Rev. 6, 389-426.

CHRistensen, C. M., STAKMAN, E. C., AND CHRISTENSEN, J. J. 1947. Variation in phytopathogenic fungi. Ann. Rev. Microbiol. I, 6I-84.

CiANTiNI, F. I944. Ricerche sulla paragglutinabilità del B. di Friedländer. Boll. Ist. sieroter. Milano 23, 47-53.

CLAPPER, W. E. 1947. Effect of sodium fluoride on metabolism of oral lactobacilli. Proc. Soc. exp. Biol. N.Y. 65, 333.

CUTTER, V. M., JR. I942a. Nuclear behavior in the Mucorales. I. The Mucor pattern. Bull. Torrey bot. Cl. $69,480-508$.

CUTTER, v. M., JR. I $942 b$. Nuclear behavior in the Mucorales. II. The Rhizopus, Phycamyces, and Sporodinia patterns. Bull. Torrey bot. Cl. 69, 592-61 6.

DARLington, C. D. 1939. The Evolution of Genetic Systems. Cambridge.

DARLINGton, C. D. 1944. Heredity, development, and infection. Nature 154, 164-169.

DELBRÜCK, M. 1946a. Bacterial viruses or bacteriophages. Biol. Rev. 2I, 30-40.

Delbrück, м. 1946b. Discussion of paper by Bonner. Cold Spr. Harb. Symp. Quant. Biol. II, 23.

DEMEREC, м. I945. Production of staphylococcus strains resistant to various concentrations of penicillin. P.N.A.S. $3^{I}$, I 6-24. $^{2}$

DEMEREC, M. 1946. Induced mutations and possible mechanisms of the transmission of heredity in Escherichia coli. P.N.A.S. 32, 36-46.

DEMEREC, M. 1947. Spontaneous and induced mutations in bacteria. Symposium on the genetics of microorganisms. Dec. 29, 1947. A.A.A.S., Chicago.

DEMEREC, M., AND FANO, U. 1945. Bacteriophage-resistant mutants in Escherichia coli. Genetics 30, I I9-136.

DEMEREC, M., AND LATARJET, R. I 946 . Mutations in bacteria induced by radiation. Cold Spr. Harb. Symp. Quant. Biol. II, 38-50.

DEVI, P., PONTECorVo, G., AND higGinbottom, c. 1947. X-ray induced mutations in dried bacteria. Nature $160,503-504$.

DIENes, L. 1946. Complex reproductive processes in bacteria. Cold Spr. Harb. Symp. Quant. Biol. II, 5I-59.

DIENES, L. I947. Further observations on the reproduction of bacilli from large bodies in Proteus cultures. Proc. Soc. exp. Biol., N.Y. 66, 97-98.

DIMock, A. W. 1939. Studies on ascosopore variants of Hypomyces ipomoea. Mycologia 3I, 709-727. 
DODGE, B. O. IgI2. Methods of culture and the morphology of the archicarp in certain species of the Ascobolacea. Bull. Torrey bot. Cl. 39, 85-1 38 .

DODGE, B. O. 1940. Second division segregation and crossing-over in the fungi. Bull. Torrey bot. $\mathrm{Cl}$. 67, 467-476.

Dodge, B. o. 1942. Heterokaryotic vigor in Neurospora. Bull. Torrey bot. Cl. 69, 759 I.

DODGE, B. O., AND SEAVER, F. J. 1946. Species of Ascobolus for genetic study. Mycologia $38,639-65$ I.

DoWDing, E. s. I931. The sexuality of the normal, giant and dwarf spores of Pleurage anserina. Ann. Bot. 45, I-I 4 .

Dubos, R. J. 1945. The Bacterial Cell. Cambridge, Mass. : Harvard University Press.

Dunn, M. s., shankman, s., CAmien, M. N., AND Block, H. 1947. The amino acid requirements of twenty-three lactic acid bacteria. 7. biol. Chem. 168, I-22.

EMERSON, R. I94I. An experimental study of the life cycles and taxonomy of Allomyces. Lloydia 4, 77-144.

EMERson, s. 1944. The induction of mutations by antibodies. P.N.A.S. 30, 179-1 83 .

EMERSON, s. 1947. Growth responses of a sulfonamide-requiring mutant strain of Neurospora. 7. Bact. 54, 195-207.

FISHER, R. A. 1947. The theory of linkage in polysomic inheritance. Philos. Trans. $B$ 233, 55-87.

FITZGERALD, R. J., AND BABBITT, D. I946. The effects of certain compounds on the lysis of Escherichia coli. 7. Immunol. 52, 12 I-1 26.

Fox, s. W., AND WARD, M. J. I 946 . The activity of modified proteins as antigens in cultures of a yeast. 7. Amer. chem. Soc. 68, 2 I 18.

FRIEs, N. 1946. X-ray induced parathiotrophy in Ophiostoma. Svensk bot. Tidskr. $40,127-140$.

FRIES, N. 1947. Experiments with different methods of isolating physiological mutations of filamentous fungi. Nature (Lond.), 159, 199 .

FROBISHER, M., AND BROWN, J. H. I927. Transmissible toxicogenicity of streptococci. Johns Hopk. Hosp. Bull. 4I, I67-I 73 .

GILES, N. H., JR. I947. Induced biochemical mutants in Absidia glauca. F. Bact. 53,504 (Abstr.).

GILES, N. H., JR., AND LEDERBERG, E. Z. I948. Induced reversions of biochemical mutants in Neurospora crassa. Amer. F. Bot. in press.

GIORgETTI, G. A. I943. Ricerche sul fenomeno della agglutinazione indotta di Cantacuzène. Boll. Ist. sieroter. Milano 22, I3-1 7 .

GRAINGER, T. H., JR. 1947. The effects of X-rays on a strain of Eberthella typhosa. 7. Bact. $53,165^{-1} 7^{2}$.

GRAY, C. H., AND TATUM, E. L. 1944. X-ray induced growth factor requirements in bacteria. P.N.A.S. $30,404-4$ Io.

GRIFFITH, F. 1928. The significance of pneumococcal types. F. Hyg., Camb. 27, II 3 -I 59 .

hansen, H. N. 1938. The dual phenomenon in imperfect fungi. Mycologia 30 , $442-455$.

HARRISON, J. A. 1947. Antigenic variation in protozoa and bacteria. Ann. Rev. Microbiol. 1 , I9-42.

haRTMANN, M. I929. Verteilung, Bestimmung, und Vererbung des Geschlechts bei den Protisten und Thallophyten. Hbuch. d. Vererbungswissenschaft. II-E. Gebrüder Borntraeger : Berlin.

HENRY, J. E., AND HENRY, R. J. I946. Studies on the relationship between bacteriophage and bacterial host cell. I. Adsorption of phage by resistant variants of Staphylococcus. 7. Bact. 52, $48 \mathrm{I}-486$.

HERSHEY, A. D. I946. Spontaneous mutations in bacterial viruses. Cold Spr. Harb. Symp. Quant. Biol. 11, 67-77.

HINSHELWOOD, c. N. 1946. The chemical kinetics of the bacterial cell. Oxford. 
HOLLAENDER, A., AND EMMONS, c. W. I94I. Wavelength dependence of mutation production in the ultraviolet with special emphasis on fungi. Cold Spr. Harb. Symp. Quant. Biol. 9, I 79-185.

HOLLAENDER, A., AND EMMONS, c. W. 1946. Induced mutations and speciation in fungi. Cold Spr. Harb. Symp. Quant. Biol. II, 78-84.

HOLTMAN, F. J. 1939. The acquisition of heterophile antigen by Eberthella typhosa and Salmonella paratyphi during culture on artificial medium. 7. Immunol. 36 , 405-4I3.

HOROWITZ, N. H., HOULAHAN, M. B., HUNGATE, M. G., AND WRIGHT, B. 1946. Mustard gas mutations in Neurospora. Science 104, 233-234.

houlahan, M. B., and Mrrchell, H. K. 1947. A suppressor in Neurospora and its use as evidence for allelism. P.N.A.S. 33, 223-229.

HUXLEY, J. S. 1942. Evolution: The Modern Synthesis. N.Y. : Harper.

JENnings, H. S. I94I. Genetics of Paramecium bursaria. II. Self-differentiation and self-fertilization of clones. Proc. Amer. phil. Soc. 85, 25-48.

JoHnson, T. 1946. Variation and the inheritance of certain characters in rust fungi. Cold Spr. Harb. Symp. Quant. Biol. II, 85-93.

JONEs, D., AND SCHATZ, A. I 946 . Methods of study of antiphage agents produced by microorganisms. 7. Bact. 52, 327-336.

JORDAN, E. O., AND BURROWs, w. 1946. Textbook of Bacteriology. 14 Ed. Phila. : Saunders.

KaUfFmanN, F. 1941. Die Bakteriologie der Salmonella-Gruppe. Copenhagen. Reprinted, Ann Arbor, Mich. 1945 : Edwards Bros.

KaUfmanN, B. P. 1942. Reversion from roughest to wild-type in Drosophila melanogaster. Genetics 37, 537-549.

KELNER, A. 1947. Secondary colonies of bacteria induced by salts of alkali metals, with special reference to Chromobacterium violaceum and other bacteria on lithium chloride agar. Amer. F. Bot. 34, 105-1 12.

KIMBALL, R. F. 1947. The induction of heritable modification in reaction to antiserum in Paramecium aurelia. Genetics 32, 486-499.

KNIEP, H. 1929. Vererbungserscheinungen bei Pilzen. Bibliogr. genet. 5, 371-475. KöHLER, F. 1935. Genetische Studien an Mucor mucedo Brefeld. Z.I.A.V. 70, 1-54. KOHN, H. I., AND HARRIS, J. S. 1942. Methionine made an essential growth factor by cultivation of $E$. coli in the presence of methionine and sulfanilamide. 7. Bact. 44, 717-718.

KRISTENSEN, M. 1944. Recherches sur la fermentation mutative des Bactéries. 4 e Communication. Acta pathologica.21, $214-238$.

kuhn, P., AND ebeling, e. 19ı6. Untersuchung über die Paragglutination. $Z$. ImmunForsch. 25, I-43.

LAMPEN, J. O., ROEPKE, R. R., AND JONES, M. J. I947. Studies on the sulfur metabolism of Escherichia coli. III. Mutant strains of $E$. coli unable to utilize sulfate for their complete sulfur requirements. Arch. Biochem. 13, 55-66.

LEDERBERG, J. 1946. Studies in bacterial genetics. 7. Bact. 53, 503 (Abstr.).

LEDERBERG, J. 1947a. The nutrition of Salmonella. Arch. Biochem. 13, 287-29o.

LEDERBERG, J. 1947b. Gene recombination and linked segregations in Escherichia coli. Genetics 32, 505-525.

LEDERBERG, J., AND TATUM, E. L. I946a. Novel genotypes in mixed cultures of biochemical mutants of bacteria. Cold Spr. Harb. Symp. Quant. Biol. II, I 13 -1 I 4 . LEDERBERG, J., AND TATUM, E. L. I946b. Gene recombination in Escherichia coli. Nature, ${ }^{1} 5^{8}, 55^{8}$.

LEDERBERG, J., AND TATUM, E. L. 1946c. Detection of biochemical mutants of microorganisms. 7. biol. Chem. $165,381 \mathrm{I}-382$.

LEgroux, R., AND GENEvRAy, J. 1933. Étude comparative entre le bacille de Whitmore et le bacille pyocyanique. Ann. inst. Pasteur. 51, 249-264.

LEVAN, A. 1947. Studies on the camphor reaction of yeast. Hereditas 33, $457-525$. 
Lindegren, c. G. 1933. The genetics of Neurospora. III. Pure bred stocks and crossing-over in $\mathcal{N}$. crassa. Bull. Torrey bot. Cl. 6o, 133-154.

LINDEGREN, c. c. 1942. The use of fungi in modern genetical analysis. Iowa St Coll. F. Sci. 16, 27 1-29o.

LINDEgRen, c. c. 1945. Yeast genetics. Bact. Rev. 9, I I I-I 70.

LINDEGREN, C. C., AND LINDEGREN, G. I942. Locally specific patterns of chromatid and chromosome interference in Neurospora. Genetics 27, I-24.

Lindegren, c. c., ANd Lindegren, G. 1946. The cytogene theory. Cold Spr. Harb. Symp. Quant. Biol. II, I I5-I29.

LINDEGREN, c. G., AND LINDEGREN, G. 1947. Mendelian inheritance of genes affecting vitamin-synthesizing ability in Saccharomyces. Ann. Missouri bot. Garden 34, 95-100.

LURIA, s. E. I 946 . Spontaneous bacterial mutations to resistance to antibacterial agents. Cold Spr. Harb. Symp. Quant. Biol. II, I30-1 37.

LURIA, s. E. 1947a. Non-independent mutations in bacteria. Genetics 32, 95 .

LURIA, S. E. I947b. Recent advances in bacterial genetics. Bact. Rev. $I 1, \mathrm{I}-40$.

LURIA, S. E. I 947 c. Reactivation of irradiated bacteriophage by transfer of selfreproducing units. P.S.A.S.S. $33,253-264$.

LURIA, S. E., AND DELBRÜCK, M. I 943 . Mutations of bacteria from virus sensitivity to virus resistance. Genetics $28,49 \mathrm{I}-5 \mathrm{II}$.

LURIA, S. E., AND LATARJET, R. I947. Ultra-violet irradiation of bacteriophage during intracellular growth. F. Bact. 54, 149-163.

LWOFF, A. 1943. L'évolution physiologique. Etude des pertes de fonctions chez les microorganismes. Paris : Masson.

LWOFF, A. 1947. Some aspects of the problem of growth factors for protozoa. Ann. Rev. Microbiol. I, IOI-I 4 .

${ }^{\mathrm{C}} \mathrm{CARTY}$, $\mathrm{M}$. I946. Chemical nature and biological specificity of the substance inducing transformations of pneumococcal types. Bact. Rev. 1o, 63-71.

$\mathrm{M}^{\mathrm{C}}$ GLINTOCK, в. I945. Neurospora. I. Preliminary observations of the chromosomes of Neurospora crassa. Amer. 7. Bot. 32, 671-678.

$\mathrm{M}^{\mathrm{C}}$ ELROY, W. D., CUSHING, J. E., AND MILLER, H. 1947. The induction of biochemical mutations in Neurospora crassa by nitrogen mustard. 7. cell. comp. Physiol. 30 , $33^{\mathrm{I}-346 .}$

$\mathrm{M}^{\mathrm{C}}$ ELROY, W. D., AND Mitchell, H. K. 1946. Enzyme studies on a temperaturesensitive mutant of Neurospora. Fed. Proc. 5, 376-379.

$\mathbf{M}^{\mathrm{C}}$ ILWAIN, $\mathrm{H}$. $\mathbf{1 9 4 6}$. The magnitude of microbial reactions involving vitamin-like compounds. Nature (Lond.) $158,898-902$.

MACKENZIE, G. M., AND BREWSTER, K. C. 1947. Determinants of virulence and avirulence in Salmonella typhimurium. Fed. Proc. 6, 429-430.

MARTIN, R., AND LAfAILle, A. 1926. Action de produits scarlatineux filtrés sur l'agglutinabilité des Streptocoques non scarlatineux et de divers autre microbes par le sérum des convalescents de scarlatine. C.R. Soc. Biol. Paris $95,784-786$.

MATHER, K. I935. Reductional and equational separation of the chromosomes in bivalents and multivalents. 7. Genet. 30, 53-78.

Mather, K. 1946. Genes. Sci. F. R. Coll. Sci. 16, 63-71.

MATHER, K., AND BEALE, G. H. 1942. The calculation and precision of linkage values from tetrad analysis. 7 . Genet. $43, \mathrm{I}-30$.

METz, c. W. I947. Duplication of chromosome parts as a factor in evolution. Amer. Nat. 8r, 81-103.

MILLER, C. P., AND BoHNHOFF, M. 1947. Two streptomycin-resistant variants of meningococcus. 7. Bact. 54, 467-48r.

MirsKy, A. E., AND POllister, A. W. 1946. Chromosin, a desoxyribose nucleoprotein complex of the cell nucleus. $\mathcal{F}$. gen. Physiol. 30, I 1 7-1 48 .

NAGEL, L. 1946. A cytological study of yeast (Saccharomyces cerevisie). Ann. Missouri bot. Garden 33, 249-288. 
NEgroni, P. 1936. Ensayos para aobtener lasreversion de la forma $R$ a la $S$ de Mycotorula albicans. Rev. Inst. bact., B. Aires 7, 393-409.

OAKBERG, E. F., AND LURIA, S. E. 1947. Mutations to sulfonamide resistance in Staphylococcus aureus. Genetics 32, 249-261.

ODA, s. 1920. Über die Erwerbung der Agglutinabilität von Colibazillen gegenüber Typhusserum. Zeitschrift d. Japan. Mikrobiolog. Gesellschaft. 13, cited in Zbl. Bact. Ref. 7I, 536. 1921.

PAINE, T. F., AND FINLAND, M. 1948. Streptomycin-sensitive, -dependent, and -resistant bacteria. Science 107, 143-144.

PANDIT, s. R., AND WILSON, G. S. 1932. The relation between specific and nonspecific agglutination in the Brucella group. 7. Hyg., Camb. 32, 45-54.

PARR, L. W., AND Simpson, W. P. 1940. Coliform "mutants," with respect to the utilization of citrate. F. Bact. $40,467-482$.

PENFold, W. J. 1913. The inhibitory selective action on bacteria of bodies related to monochloroacetic acid. F. Hyg., Camb. $13,35-48$.

Pollock, M. R. 1946. Adaptation of " nitratase" in washed suspensions of bacteria. Brit. F. expt. Path. 27, 419-432.

Pontecorvo, G. 1946. Genetic systems based on heterocaryosis. Cold Spr. Harb. Symp. Quant. Biol. II, 193-201.

POWERS, E. L., JR. 1943. The mating type of double animals in Euplotes patella. Amer. Midl. Nat. 30, 1 75-195.

PREER, J. R. 1946. Some properties of a genetic cytoplasmic factor in Paramecium. P.N.A.S. 32, 247-253.

PREER, J. R., JR. 1947. Some properties of the killer cytoplasmic factor, kappa. Symposium, Dec. 29, 1947. A.A.A.S., Chicago.

PROchazKA, J. 1930. Recherches sur l'agglutinabilité acquise par les Streptocoques au contact de produits filtrés scarlatineux. C.R. Soc. Biol., Paris 104, 387-389.

REED, G. B. 1933. A hypothetical view of bacterial variation. F. Bact. 25, $580-586$.

RHOADES, M. M. I94I. The genetic control of mutability in maize. Cold Spr. Harb. Symp. Quant. Biol. 9, 1 38-1 44.

RIZET, R. I939. Sur les spores dimorphes et l'hérédité de leurs caractères chez un nouvel Ascobolus hétérothallique. C.R. Acad. Sci., Paris 208, 1669-1671.

RIZET, R. 1942. Les resultats d'ordre génétique et la problème de la sexualité chez l'Ascomycète Podospora anserina. Rev. Mycol. 7, 89-97.

Robinow, C. F. 1944. Cytological observations on Bact. coli, etc. F. Hyg., Camb. 43,4 I $3-423$.

ROBBINS, W. J., AND KAVANAGH, v. 1942. Vitamin deficiencies of the filamentous fungi. Bot. Rev. 8, 41 I-47I.

ROEPKE, R. R., LIBBY, R. L., AND SMALL, M. H. 1944. Mutation or variation of Escherichia coli with respect to growth requirements. F. Bact. 48, 401-412.

RYAN, F. J. 1943. Crossing-over and second-division segregation in fungi. Bull. Torrey bot. Cl. 70, 605-61 I.

Ryan, F. J. 1946a. The application of Neurospora to bioassay. Fed. Proc. 3, 366-369.

RYAN, F. J. 1946b. Back-mutation and adaptation of nutritional mutants. Cold Spr. Harb. Symp. Quant. Biol. 11, 21 5-227.

RYAN, F. J., BALleNTINE, R., STOLOVY, E., CORSON, M. E., AND SCHNEIDER, L. K. 1945 . The biosynthesis of pantothenic acid. F. Amer. chem. Soc. goo, 1857-1858.

RYAN, F. J., AND LEDERBERG, J. 1946. Reverse mutation and adaptation of leucineless Neurospora. P.N.A.S. 32, I63-1 73, 193.

SACQUEPEE, E., LIÈGOIS, AND FRICKER, J. I 229 . Recherches sur l'agglutinabilité conferée au Streptocoque par les filtrats de produits scarlatins. C.R. Soc. Biol., Paris 100, I1 $87-1189$.

SAlus, G. I9I 7. Zur Paragglutination. Z Zbl. Bakt. (I.) 8o, 196-200.

SANSOME, E. R. 1946. Induction of " gigas" forms of Penicillium notatum by treatment with camphor vapour. Nature (Lond.), 157, 843-844. 
SChWEnkenbecher, D. 1940. Ueber das Phänomen der induzierten Agglutination von Cantacuzène. Z. ImmunForsch. 98, 253-26o.

SHAPIRO, A. 1946. The kinetics of growth and mutation in bacteria. Cold Spr. Harb. Symp. Quant. Biol. II, 228-235.

SHAY, J. R., AND KEITT, G. W. 1945. The inheritance of certain mutant characters in Venturia inaequalis. F. agric. Res. 70, 31-41.

sмiтн, G. м. 1946. The nature of sexuality in Chlamydomonas. Amer. F. Bot. 33, 625-630.

SONNEBORN, T. M. 194I. Sexuality in unicellular organisms, Chap. 14 in Protozoa in Biological Research, ed. Calkins, G. N., and Summers, F. M. New York : Columbia.

SONNEBORN, T. M. 1946. Experimental control of the concentration of cytoplasmic factors in Paramecium. Cold. Spr. Harb. Symp. Quant. Biol. II, 236-248.

SONNEBorn, т. м. 1947a. Recent advances in the genetics of Paramecium and Euplotes. Adv. Genetics, I, 263-358.

SONNEBORN, T. M. 1947b. Symposium on the plasmagenes, genes and character in Paramecium aurelia. Dec. 29, 1947. A.A.A.S., Chicago.

SONNEBORN, T. M., DIPPELl, R. v., AND JACOBSON, W. 1947. Some properties of kappa (killer cytoplasmic factor) and of paramecin (killer substance) in Paramecium aurelia, variety 4. Genetics 32, 106 (Abstr.).

SPIEGELMAN, S. 1946. Nuclear and cytoplasmic factors controlling enzymatic constitution. Cold Spr. Harb. Symp. Quant. Biol. II, 256-274.

Stahmann, м. A., AND STAUfFer, J. F. 1947. Induction of mutants in Penicillium notatum by methyl-bis $(\beta$-chloroethyl)amine. Science 106, 35-36.

STAKMAN, E. G., KeRnKAMP, M. F., MARTIN, W. J., AND KING, T. H. 1943. The inheritance of a white mutant character in Ustilago zee. Phyopathology, 33, 943-949.

STEINBERG, R. A., AND THOM, C. 1942. Reversions in morphology of nitrite-induced "mutants" of Aspergilli grown on amino acids. 7. agr. Res. 64, 645-652.

STEWART, F. H. 1943. A review of some recent work on papillary variation in bacteria and bacterial cytology. 7. Hyg., Camb. 43, 136-1 41.

STIER, T. J. B., AND GASTOR, J. G. B. 194I. On the production and use of permanently altered strains of yeast for studies of in vivo metabolic organization. 7 . gen. Physiol. 25, 229-234.

STONE, W. s., WYSs, O., AND HAAS, F. 1947. The production of mutations in Staphylococcus aureus by irradiation of the substrate. P.N.A.S. 33, 359-366.

SUBRAmaniam, M. K. 1945. Induction of polyploidy in Saccharomyces cerevisie. Curr. Sci. 14, 234.

TAтUM, E. L. 1945. X-ray induced mutant strains of Escherichia coli. P.N.A.S. 3I, 215-219.

TATUM, E. L. 1946. Induced biochemical mutations in bacteria. Cold Spr. Harb. Symp. Quant. Biol. II, 278-284.

TATUM, E. L. 1947. Chemically induced mutations and their bearing on carcinogenesis. Ann. N.Y. Acad. Sci. 49, 87-97.

TATUM, E. L., AND BELL, T. T. 1946. Neurospora. III. Biosynthesis of thiamin. Amer. F. Bot. 33, 15-20.

TATUM, E. L., AND LEDERBERG, J. 1947. Gene recombination in the bacterium, Escherichia coli. 7. Bact. 53, 673-684.

THAYSEN, A. C., AND MORRIS, M. 1943. Preparation of a giant strain of Torulopsis utilis. Nature (Lond.) 152, 526-528.

тномаs, Р. т. 1945. Experimental imitation of tumour conditions. Nature (Lond.), I56, 738-740.

TMMOFEEFF-RESSOVSKY, N. W. 1937. Experimentelle Mutations-forschung in der Vererbungslehre. Dresden : Steinkopf.

UBER, F. M., AND GODDARD, D. R. I934. Influence of death criteria on the X-ray survival curves of the fungus, Neurospora. F. gen. Physiol. 17, 577-59o. 
VAN NIEL, C. B. 1946. The classification and natural relationships of bacteria. Cold Spr. Harb. Symp. Quant. Biol. 1I, 285-300.

VAN SACEGHEM, R. 1935. Sur la transformation de bactéries non-pathogènes en bactéries pathogènes dans le filtrat de bactéries pathogènes. C.R. Soc. Biol., Paris 120, 1379-1380.

VEBLEN, B. B. 1929. Are there bacterial protein hybrids? Proc. Soc. exp. Biol. N.Y. $27,204$.

voN STOSCH, H. A. 1935. Untersuchungen über die Entwicklungsgeschichte der Myxomyceten. Sexualität und Apogamie bei Didymiaceen. Planta 23, 623656 .

WEIL, A. J., AND BINDER, M. 1947. Experimental type transformation of Shigella paradysenterice (Flexner). Proc. Soc. exp. Biol. N.Y. 66, 349-352.

WEIR, J. A. I947. A source of genes for evolutionary progress. Genetics 32, I I I-I I 2 (Abstr.).

White, P. BRUCE. I926. Further studies of the Salmonella group. Spec. Rep. Ser. med. Res. Comm. ro3.

WhITEHouse, F. L. K., AND hALDANE, J. B. S. 1946. Symmetrical and assymetrical reduction in Ascomycetes. 7. Genet. 47, 208-2 12.

Wiggert, W. P., AND WERkman, c. H. 1939. Fluoride sensitivity of Propionibacterium pentosaceum as a function of growth conditions. Biochem. 7. 33, r $06 \mathrm{I}-\mathrm{I} 06 \mathrm{~g}$.

WILliamson, J., BERTRAM, D. S., AND LOURIE, E. M. I947. Acquired resistance to paludrine in Plasmodium gallinaceum. Nature (Lond.) $159,885-886$.

WINGE, ø., AND LAUSTSEN, o. 1937. On two types of spore germination and on genetic segregations in Saccharomyces demonstrated through single-spore cultures. C.R. Lab. Carlsberg, Ser. physiol. 22, 99-I I 9.

WINKLeR, H. 1932. Konversions-Theorie und Austausch-Theorie. Biol. Zbl. 52, I63-189.

WITKIN, в. M. 1947a. Genetics of resistance to radiation in Escherichia coli. Genetics $32,221-248$.

WITKIN, в. M. 1947b. Mutations in Escherichia coli induced by chemical agents. Cold Spr. Harb. Symp. Quant. Biol. 12, 256-269.

WOllman, E. 1947. Essai d'analyse des besoins en tryptophane de mutants d'Escherichia coli resistants au bactériophage. Ann. Inst. Pasteur 73, 1082-1088.

WOllman, E., AND wollman, E. I925. Sur la transmission parahéréditaire de caractères chez les bactéries. C.R. Soc. Biol., Paris 93, 1568-1 569.

wYss, o., STONE, w. s., AND CLARK, J. B. I947. The production of mutations in Staphylococcus aureus by chemical treatment of the substrate. F. Bact. 54, 767-772. ZICKLER, H. I934. Genetische Untersuchungen an einem heterothallischem Askomyzeten (Bombardia lunata n.sp.). Planta 22, 572-6I 3 .

zOzLleR, C., AND MEERSSEMAN, B. 1927. Le phénomène "d'agglutionabilité transmissible." C.R. Soc. Biol., Paris 96, 760-76r. 